\title{
The Discount to NAV of Distressed Open-End Real Estate Funds
}

\author{
Sebastian Schnejdar • Michael Heinrich \\ René-Ojas Woltering · Steffen Sebastian
}

Published in "The journal of real estate finance and economics", 2020, vol. 61, pp. 80-114, which should be cited to refer to this work.

DOI : $10.1007 /$ s11146-018-9694-8

16 December 2018

\begin{abstract}
This paper examines the discount to NAV in the context of distressed German open-end real estate funds. This is a unique setting to study NAV discounts because distressed real estate funds are forced to sell off their property portfolios and pay out the proceeds to investors. In contrast, the discount to NAV of closed-end funds or REITs can theoretically persist forever. This enables us to study how investors price the risks associated with the forced liquidation of direct-property portfolios. Our hand-collected dataset covers the complete crisis and post-crisis period from October 2008 through June 2016. Using panel regression methods, we find that the discount to NAV is driven by fundamental risk because it is positively correlated with a funds leverage ratio and it decreases with the share of liquid assets. We also provide evidence that the discount is related to conflicts of interest between investors and fund management. Besides these fund-specific factors, we find that NAV discounts are driven by spillover effects from the announcement of other funds' liquidations, as well as by investor sentiment, which is proxied by the aggregate level of capital flows into the industry and by the degree of macroeconomic uncertainty.
\end{abstract}

Keywords Open-End Real Estate Funds · Liquidity Transformation · Discount to NAV · Liquidity Crisis · Uncertainty $\cdot$ Spillover Effects

JEL classification $\mathrm{G} 230 \cdot \mathrm{L} 85 \cdot \mathrm{G} 33$

Sebastian Schnejdar

IREBS International Real Estate Business School, University of Regensburg

Universitätsstraße 31, 93053, Regensburg, Germany

E-mail: sebastianschnejdar@web.de (corresponding author)

Michael Heinrich

IREBS International Real Estate Business School, University of Regensburg

Universitätsstraße 31, 93053, Regensburg, Germany

E-mail: michael.heinrich@irebs.de

René-Ojas Woltering

Ecole hôteliére de Lausanne, HES-SO

University of Applied Sciences Western Switzerland, Lausanne, Switzerland

E-mail: rene-ojas.woltering@ehl.ch

Steffen Sebastian

IREBS International Real Estate Business School, University of Regensburg

Universitätsstraße 31, 93053, Regensburg, Germany

E-mail: steffen.sebastian@irebs.de 


\section{Introduction}

Open-end real estate funds, besides REITs and closed-end funds, represent one of the most significant real estate investment vehicles worldwide ${ }^{1}$, with Germany being the largest market. As of December 2016, this asset class had investments totalling about EUR 145 billion.

Investors in these funds trade directly with the fund or its sponsor, which sells and redeems shares on a regular basis. The price per share is determined by the sponsor, and is based on the net asset value (NAV) per share, which is calculated as the market value of all assets less the market value of all liabilities divided by the number of outstanding shares. Each month, independent appraisers reappraise one-twelfth of the entire portfolio. ${ }^{2}$ Due to their NAV-based pricing system, open-end real estate funds are usually less volatile than REITs or real estate stocks, which are subject to stock market risk. This, however, comes at the cost of increased liquidity risk. The discrepancy between the daily liquidity of fund shares and the illiquidity of the underlying direct property investments is referred to as "bank run" risk (Bannier et al., 2008; Weistroffer and Sebastian, 2015). To maintain the "buy-back" guarantee, open-end real estate funds tend to hold high cash reserves. In Germany, at least $5 \%$ of a fund's NAV must be held in cash or liquid assets. In practice, average liquidity ratios tend to fluctuate between $20 \%$ and $30 \%$ (see Downs et al., 2016a), although these reserves may prove inadequate during times of market turmoil.

A recent example of what havoc market turmoil can wreak can be seen with the Brexit Referendum in the U.K. on June 23, 2016. The decision to leave the European Union came as a surprise to many investors, and led to massive redemptions from U.K. open-end real estate funds. As a result, seven public U.K. funds, representing half the total open-end real estate fund assets under management, were forced to suspend share redemptions. ${ }^{3}$

The German open-end fund industry was hit even harder in the aftermath of the 2008 global financial crisis. Between October 2008, the month after the Lehman Brothers bankruptcy, and October 2010, ten public German open-end real estate funds had to suspend share redemptions. None of these funds could raise enough liquidity to reopen and fulfill all the redemption requests. Thus, each of them had to liquidate its portfolio and pay out the proceeds to investors. ${ }^{4}$

The closure of these funds lead to the most severe fund crisis in the history of German open-end real estate funds. ${ }^{5}$

Besides waiting for the stepwise liquidation of fund assets, German open-end real estate fund investors have the option of selling their shares on the secondary market. This option is available both for funds in a liquidation phase, as well as those under share redemption suspensions. In this paper, we refer to both types as "distressed" open-end real estate funds.

\footnotetext{
1 See Downs et al. (2016b) for a recent overview.

2 See Weistroffer and Sebastian (2015) and Fecht and Wedow (2014).

3 M\&G Property Portfolio, Henderson UK Property PAIF, Standard Life UK Real Estate Fund, Aviva Investors Property trust, Columbia Threadneedle UK Property Authorised Investment Fund (PAIF), Pramerica Property Investment, Canada Life UK Property Fund, and Aberdeen UK Property Fund.

4 The next section provides some regulatory background on the liquidation regime of German open-end real estate funds and an overview of the recent crisis.

5 At the beginning of our sample period in October 2008, all German open-end real estate funds had a total fund size of EUR 107 billion. The asset class is divided into open-end real estate retail funds and institutional funds ("Spezialfonds"). In October 2008, the overall number of German open-end real estate retail funds was 43 with a total fund size of EUR 84 billion. Excluding semi-institutional funds, there were 24 retail-focused funds with a total fund size of EUR 69 billion. In total, 10 became distressed in the aftermath of the financial crisis. The total fund size of the distressed funds in October 2008 was about 30 billion Euros. The distressed funds in our sample therefore represent a significant part of the German open-end real estate fund industry.
} 
Although distressed open-end real estate funds continue to regularly publish NAVs per share, the price per share on the secondary market becomes a function of supply and demand. ${ }^{6}$

The principles of supply and demand suggest that secondary market prices should be lower than NAV if a large number of investors choose not to wait for the liquidation process to proceed. Furthermore, the loss of the "buy-back" guarantee, as well as the shift from a relatively stable appraisal-based pricing system to more volatile transaction-based share prices, justifies a risk premium. Figure 1 confirms this intuition. A comparison of the total Fund Size (based on NAVs) of all distressed real estate funds (blue line) and their total market capitalization based on secondary market share prices (black line) reveals that investors engaging in secondary market trading on average accept substantial discounts to NAV.

Beyond these general considerations, however, little is known about the specific factors that explain the discount to NAV of distressed open-end real estate funds. Figure 2 shows that the discounts of distressed real estate funds differ substantially across funds. Therefore, we aim to identify the fund-specific factors behind the heterogeneity of NAV spreads across funds. In addition, and despite the different closing dates, the individual discounts to NAV tend to be highly correlated between funds. Thus, we explore whether the correlations of NAV discounts are driven by marketwide sentiment.

Our goal is to answer these questions by providing a comprehensive analysis of the factors that explain discounts to NAV of distressed open-end real estate funds. NAV discounts have already been extensively studied in the context of closed-end funds (e.g., Lee et al., 1991; Pontiff, 1996; Chay and Trzcinka, 1999) and of publicly traded REITs or real estate operating companies (REOCs) (e.g., Barkham and Ward, 1999; Brounen and ter Laak, 2005; Patel et al., 2009). The major difference between these strands of the literature and our paper is that the discounts to NAV of closed-end funds or REITs may theoretically persist forever. In contrast, the forced liquidation of the funds in our sample ensures investors actually receive payouts. This enables us to study NAV discounts in a new setting. It should be noted, however, that the "forced liquidation" may result result in a poorer bargaining position for selling property, which by itself may justify a discount to NAV. Understanding what drives NAV discounts of distressed open-end real estate funds is relevant for all market participants. The magnitude of the discount to NAV is not only relevant for existing investors, for whom it represents a loss of shareholder value, but also for potential new investors, for whom it may represent an investment opportunity. Fund families may also be concerned about discounts to NAV. Their prestige may be damaged if investors not only suffer liquidity constraints, but also high discounts to NAV on the secondary market. Moreover, regulators may be interested in fostering an environment where discounts to NAV are as small as possible. Finally, market participants from other countries with established open-end real estate fund regimes may be able to learn from the German experience.

\footnotetext{
6 During normal periods, NAV per share is measured on a daily basis and changes for example as rental payments are received, interest payments are made, or properties are reappraised. The accounting standards with respect to the daily calculation of NAV per share are not lowered as funds suspend the redemption of shares or enter the stage of fund liquidation.
} 
Our empirical study is based on a monthly panel of nine distressed open-end real estate funds in Germany. ${ }^{7}$ It covers crisis period from October 2008, when the first funds suspended share redemptions, through June $2016 .^{8}$

Our set of explanatory variables is comprised of fund-specific, external and control variables. We use the leverage ratio, the liquidity ratio, management fees, extraordinary payouts, economic growth of target markets, and the tenancy rate of a fund's properties to explain the fund-specific, or idiosyncratic, part of the NAV discount. External variables are used to capture the systematic component of the discount to NAV. Here, we use closures of other funds and the total number of funds in liquidation. Both variables can also be interpreted as spillover effects from other real estate funds. Moreover, we account for the total amount of net fund flows to all real estate funds that continue to sell and redeem shares. We also include macroeconomic uncertainty indices, which have become increasingly popular as a means to account for the rising degree of economic uncertainty in the aftermath of the global financial crisis. We control for a fund's past performance, size, and share of institutional holdings.

Using fixed-effects panel regressions to explain the discount to NAV, we provide evidence that fundamental, fund-specific variables play a substantial role. In particular, we find that the discount to NAV increases with rising leverage ratios, and decreases with the ratio of cash holdings. This is consistent with the idea that the risk of distressed real estate funds depends primarily on whether appraisal values are reliable. This risk increases (decreases) with rising leverage (liquidity). We also document that the discount to NAV is related to potential conflicts of interest between investors and fund management. It increases concurrent with management fees, and is smaller for funds with higher extraordinary payouts, suggesting there is a benefit of investor-friendly behavior. We find evidence of industrywide spillover effects because the discount to NAV increases when other funds announce liquidations. Finally, we document that the discount to NAV is related to our proxies for investor sentiment, as discounts to NAV decrease with the total level of capital flows into the open-end fund industry, and increase with the degree of macroeconomic uncertainty.

In additional analyses we explore whether NAV discounts were too high, by analyzing the performance of distressed funds as a function of the discount to NAV. Our results suggest

\footnotetext{
7 Nine of the ten closed retail funds were relatively comparable to each other. However, the HansaImmobilia Fund was liquidated without adhering to the closing period of twenty-four months. We exclude that fund from our dataset. Moreover, we do not consider the UniImmo Global fund, which closed only temporarily until the revaluations of the fund's Japanese properties was finalized. This revaluation was necessary due to the Tohoku earthquake and the resulting tsunami as well es the following nuclear risks in 2011.

The funds in our sample are predominantly aimed at retail investors, which represent about $60 \%$ to $90 \%$ of the assets under management. However, as with common mutual funds, institutional investors also have the opportunity to invest in these funds. In fact, institutional investors often have the ability to buy fund shares directly from the fund without paying a transaction fee. In Germany, there are two other forms of open-end real estate funds: 1) institutional real estate funds, which are exclusively aimed at institutional investors. For these funds, data availability is very scarce. And 2) semi-institutional real estate funds. These funds operate according to the same regulatory regime (e.g. NAV-based pricing system, reporting requirements, etc.), however, only institutional investors or qualified investors (high net worth individuals), with minimum investment amounts from EUR 10.000 to EUR 1.0 million are allowed to invest in these funds. While we do have data on these funds, their nature is very different from the funds that are the focus of our analysis, where the supply and demand of fund shares on the secondary market, and, hence, ultimately the discount to NAV per share, is determined by the unwillingness of retail investors to go through the liquidation process. Therefore, we do not consider them in our sample.

8 It is important to note that our analysis deliberately focuses on distressed funds. Only funds in this subsample can exhibit a discount to NAV. In contrast, investors in non-distressed funds can sell their shares back to the fund at the NAV per share. For this reason, non-distressed funds cannot exhibit a discount to NAV, which makes them irrelevant for our analysis. For this reason, our analysis is naturally restricted to distressed real estate funds. Our results are therefore unlikely to suffer from sample selection bias or endogeneity issues.
} 
that, on average, NAV discounts of more than $30 \%$ appear excessive. Furthermore, we find that funds with the highest NAV discounts perform significantly better than funds with the lowest NAV discounts.

The remainder of this paper is organized as follows. Section 2 provides an overview of the German open-end fund crisis and some regulatory details. Section 3 describes our set of explanatory variables and how they relate to the extant literature. Section 4 describes our data, while our regression results are in section 5. Section 6 provides an performance analysis of distressed real estate funds as a function of the NAV discount. Section 7 concludes.

\section{The German Open-end Fund Crisis and Regulatory Background}

German open-end real estate funds are at risk of becoming distressed when their liquidity ratios are critically low. By German investment law, they must hold at least five percent of their assets in the form of highly liquid money market investments in order to sustain the buyback guarantee. When the liquidity ratio of a German open-end fund falls below this threshold, it is forced to suspend the redemption of shares until it has raised enough liquidity to reopen. In practice, some funds already choose to suspend the redemption of shares as soon as it becomes foreseeable that the liquidity ratio will fall below the five percent threshold.

The key to managing the risk of financial distress is a sufficient liquidity ratio. In the mid- to long-term, the liquidity ratio can be steered through property acquisitions and disposals. While a high liquidity ratio minimizes the risk of falling below the 5\% threshold, a drawback of this strategy is that the typically low-yielding cash holdings can lead to underperformance relative to a fund's peers. In the short term, a fund's liquidity ratio is primarily determined by its net fund flows, i.e. the buying and selling decisions of fund investors. Downs et al. (2016) find that investors in open-end real estate funds chase past performance at an aggregate level and more than proportionally buy relative outperformers than they sell relative underperformers. The authors also document that fund investors tend to sell underperformers more heavily when their liquidity ratios are low, thereby enforcing a vicious circle.

Asset fire sales can only be seen as a last way to increase the liquidity ratio in the short run, as the potential negative bad press associated with low sales prices may trigger further share redemptions from existing investors.

The determinants of fund closures are documented by Schnejdar et al. (2018). The authors document that the fund closure probability is positively related to a large share of institutional investors. This finding is consistent with the hypothesis that institutional investors misused open-end funds as a higher-yielding money-market substitute as opposed to a strategic real estate investment. Furthermore, bank-owned funds, which are characterized by strong distribution networks, obtain a lower closure probability. The typically personal relationships with the banks and their clients may have helped to convince the clients to remain invested in the funds. Finally, the authors find that fund closures are driven by spillover effects. A fund's closure probability increases when other funds announce the suspension of share redemptions.

When a German open-end real estate fund suspends share redemptions, it tries to reopen by selling enough properties to increase its liquidity reserves an ultimately fulfil all redemption requests. Funds that fail to reopen within twenty-four months are forced to liquidate their portfolios and pay out the proceeds to investors. 
Selling properties within a particular time frame can be difficult, however, especially during, times of low transaction activity in the real estate markets, such as during the aftermath of the 2008 global financial crisis. Lower asking prices can help to increase the probability of a sale. However, in order to avoid "fire sales", the German legislature enacted sale price restrictions tied to appraisal values. During the first twelve months following share redemption suspensions, funds are thus not permitted to sell properties below their most recent appraised values. After the first twelve months, the funds may sell properties at a discount of up to $10 \%$ relative to the last appraised value.

These legal restrictions may be viewed as overly burdensome for distressed real estate funds that are attempting to reopen. On the other hand, funds are allowed to reappraise their properties prior to transactions, which effectively enables fire sale prices. However, large discounts of transaction prices relative to previous appraisal values can destroy trust in a fund's appraisal values. A vicious circle may result if a lack of confidence in a funds published NAVs leads to higher redemption requests when the fund attempts to reopen.

The liquidation process is overseen by the Federal Financial Supervisory Authority (BaFin), which determines an individual time line for every fund (typically between three and five years). Subsequently, the investment company is no longer in charge of managing further liquidations. Rather, a third-party depository bank is tasked with selling the entire real estate portfolio. ${ }^{9}$ Funds in liquidation may sell properties at discounts of up to $20 \%$ during the first twelve months of the liquidation process. Twelve months later, discounts of up to $30 \%$ are authorized. After the determined liquidation date, the fund's management is transferred to a depository bank, which can sell the assets without restrictions. This event also leads to an extraordinary tax burden for all investors, because a land transfer tax applies.

Figure 3 provides a detailed overview of the number and total fund size of German openend real estate funds that either suspended share redemptions (orange bars), or were already in the process of fund liquidation (red bars). The graph also shows the number and total fund size of reopenings (green bars). The crisis began in October 2008, when nine funds with total assets under management of EUR 28 billion suspended share redemptions. The reopening of seven of these funds over the following twelve months indicated a recovery. However, these reopenings proved unsustainable. Through May 2010, the total fund size of funds that had suspended share redemptions had returned to previous levels of around EUR 27 billion, but the first fund liquidations were announced in October 2010. As of August 2012, all previously suspended funds had entered the liquidation phase. ${ }^{10}$ The shrinking fund size over time shown in Figure 3 is due to two effects: 1) distributions to investors facilitated by property disposals, and 2) falling property appraisal values following impairments. As of June 2016, EUR 10 billion of invested capital was yet to be distributed to shareholders under liquidation.

\section{Related Literature and Hypotheses}

To the best of our knowledge, this is the first paper to address NAV discounts of distressed funds in general, and distressed real estate funds in particular. During normal times, supply and demand for open-end funds is balanced through a variable number of fund shares, which is why they are called open-end. When open-end real estate funds can no longer maintain

\footnotetext{
9 As a consequence of the open-end real estate fund crisis, the regulatory regime was modified several times. However, our analysis is unaffected by these changes because all the funds in our analysis were liquidated under the prior investment laws (InvG, effective from 1/1/2004 -7/22/2013).

10 Table 1 provides the exact dates of all the major events for the distressed real estate funds in our sample.
} 
the buy-back guarantee, they become distressed and can only be traded on the secondary market. Since the sponsor of the fund no longer redeems fund shares, the number of shares is constant and thus supply and demand can only be balanced through a variable share price on the secondary market. This regime shift also implies that distressed real estate funds are actually no longer "open-end", but rather "closed-end" due to the fixed number of shares and the flexible share price, which is typically lower than the NAV per share. This situation is very similar to closed-end mutual funds, where also a constant number of shares are traded on the secondary market at a discount to the NAV. For this reason, some of our hypotheses relate to the closed-end fund literature. In essence, the basket of stocks held by closedend mutual funds trades for less than the combined market value of the individual stocks held in the portfolio (Cherkes, 2003). Thus, even in the presence of a professional fund management, the pooling appears to reduce the portfolios worth. According to Lee et al. (1991), closed-end fund discounts are the result of private investor sentiment, who are also referred to as "noise traders". An irrational downturn in investor sentiment leads to larger discounts. Therefore, holding a closed-end mutual fund portfolio can result in larger risk, or uncertainty, than holding the underlying funds assets.

Our research is also related to the literature on the discounts (or premia) to NAV of publicly traded REITs or REOCs and the literature about German open-end real estate funds in general. ${ }^{11}$ It is not uncommon for REITs to trade at a premium to their NAV, but they also frequently trade at discounts to NAV. Similarly to closed-end funds, Barkham and Ward (1999) find evidence that supports the noise trader hypothesis for listed property companies in the U.K.

The difference between these two strands of the literature and our paper is that distressed real estate funds are forced to sell off their property portfolios and pay out the proceeds to investors. Open-end real estate funds can be seen as a mixed form between listed and direct real estate. While REITs are as liquid as common stocks, open-end real estate funds are only liquid as long as investors can redeem their shares to the fund or the sponsor of the fund. On the other hand, the shares of "closed" open-end real estate fund can be traded on the secondary markets, often at substantial discounts. In this context, the discount to NAV of distressed open-end real estate funds can be interpreted, according to Schweizer et al. (2013), as the price of reduced liquidity and uncertainty regarding the appraisal values of the fund's properties. This enables us to study how investors price the risks associated with the forced liquidation of a direct-property portfolio.

Figure 2 shows that the discounts to NAV of distressed real estate funds are heterogeneous across funds, which suggests they are driven by fund-specific, or idiosyncratic, variables. Our first three hypotheses and the respective proxy variables reflect these potential internal factors. Figure 2 also reveals that the discounts to NAV are correlated between the funds over time. Lee et al. (1991) document that this is true of closed-end funds as well, which indicates that NAV discounts may be affected by either industrywide or macroeconomic sentiment. Hypotheses 4 and 5 reflect these potential external factors.

\section{Financial Leverage}

The anticipation of lower transaction prices compared to current appraisal values is a potential rational explanation for substantial discounts to NAV. The effect of lower appraisal values or transaction prices on a fund's NAV is amplified further by the amount of financial

\footnotetext{
11 In contrast to common stocks and mutual funds, there is no public market for the real estate assets alone.
} 
leverage used by a fund. For example, if investors anticipate that the next appraisal round will reveal a $10 \%$ decrease in property values, then a leverage ratio of $50 \%$ would justify a $20 \%$ discount to NAV, assuming all the fund's assets are invested in real estate. Thus, the leverage ratio risk may be reflected in a lower market price relative to the NAV per share. Using data on European public property companies, Bond and Shilling (2004) as well as Brounen and ter Laak (2005) find that leverage is positively correlated with NAV discounts. Likewise, the discount to NAV of distressed open-end real estate funds may also increase with the leverage ratio.

Mirroring this principle, the opposite effect may occur when a fund has high cash reserves. Because distressed real estate funds may be forced to sell their portfolios, they tend to exhibit rising liquidity ratios until they pay out proceeds to investors. In contrast to the appraisal values of the properties, a fund's liquid assets generally have little to zero market or appraisal risk, and can be considered safe for investors. Consistent with the idea that investors appreciate higher liquidity ratios, Fecht and Wedow (2014) find that open-end real estate funds with lower liquidity ratios are associated with higher capital outflows. Therefore, we expect a negative relationship between the liquidity ratio of a fund and its discount to NAV. The potential impact of the fundamental risk associated with the degree of financial leverage employed by a fund leads to Hypothesis 1 :

Hypothesis 1: The discount to NAV increases (decreases) with the leverage (liquidity) ratio of a fund.

\section{Conflicts of Interest}

According to the closed-end fund literature, management costs are an important, but ambivalent, determinant of NAV discounts. For example, if the expected return on the equity portfolio of a closed-end fund is $7 \%$, fund fees of $1.5 \%$ per year can considerably reduce that return after fees. Gemmill and Thomas (2002) document that small closed-end funds, which often obtain high fees, exhibit larger discounts to NAV. On the other hand, Lenkey (2015) shows that the relation between NAV discounts and management fees is not stable due to two opposing effects 1) larger fees reduce shareholder value 2) More skilled managers can charge higher fees. During normal times, investors in open-end real estate funds can "vote with their feet", and sell their shares back to the fund if they believe management fees are excessive. This would decrease assets under management and hence fee income, thereby incentivizing fund managers to (again) act in line with investor interests. In contrast, investors in distressed real estate funds do not have the option to redeem their shares to the fund, and are fully exposed to the fees set by management. They can only choose to sell their shares on the secondary market, where assets under management remain unaffected. This potential conflict of interest between fund management and investors can have an effect on NAV discounts if investors in expensive funds are more inclined to sell their shares on the secondary market.

A further conflict of interest may arises in the context of extraordinary payouts. During normal times, investors in open-end real estate funds receive an annual dividend. When a distressed fund is in the process of liquidating, however, investors receive additional "extraordinary" payouts from the stepwise liquidation of the fund's real estate assets, often on a semiannual basis. Investors in distressed open-end real estate funds prefer high extraordinary payouts, because this way they receive their locked-up funds without having to accept a discount to NAV on the secondary market. In contrast, the fund management has an incentive to delay the liquidation process and retain liquidity to maximize their fee income, which 
is typically a direct function of the fund size. We therefore believe that extraordinary distributions are a good proxy to measure whether fund management acts in the best interest of the investors. Accordingly, distressed funds with higher payout ratios are expected to trade at lower discounts to NAV compared to their peers with smaller payout ratios. Furthermore, investors in funds with large NAV discounts may appreciate payouts, because the dividend yields are considerably higher when calculated with respect to discounted share prices rather than NAVs. Consistent with this idea, the literature on the closed-end fund puzzle finds that low dividend payouts lead to larger discounts to NAV (Pontiff, 1996; Gemmill and Thomas, 2002; Cherkes, 2003; and Malkiel and Xu, 2005). The potential conflict of interest between fund management and investors leads to our second hypothesis concerning the discount to NAV of distressed real estate funds:

Hypothesis 2: The discount to NAV increases in the presence of apparent conflicts of interest between fund management and investors.

\section{Portfolio Quality}

The anticipation of lower transaction prices than current appraisal values is a potentially rational explanation for substantial discounts to NAV. De Wit and van Dijk (2003) find that the GDP growth rate is a useful variable to forecast the direction of direct real estate prices. The authors find that GDP positively influences direct real estate prices. Accordingly, NAV discounts may be smaller if the fund's assets are located in countries with positive GDP developments.

Another proxy for the quality of a fund's property portfolio is the average tenancy rate. Wurtzebach et al. (1991) find that high office vacancy rates (or low tenancy rates) are associated with decreasing commercial real estate returns in the U.S.. In addition Weistroffer and Sebastian (2015) also use the vacancy rate as a measure of portfolio quality in their study about the accuracy of German open-end real estate fund's real estate asset valuation. Accordingly, higher tenancy rates may be perceived as a signal of the quality of a fund's property portfolio, as well as more stable cash flows and property values. In other words, we posit that funds with higher tenancy rates are less likely to devalue their properties in the near future. Hence, we expect a negative relationship between a funds tenancy rate and its discount to NAV. Our proxies for fund portfolio quality lead to Hypothesis 3:

Hypothesis 3: The discount to NAV decreases with a fund's property portfolio quality.

\section{Spillover Effects}

Figure 2 shows the correlation of NAV discounts between funds over time, and suggests the presence of a systematic component simultaneously affecting the NAV discounts of all funds. The financial fragility of open-end real estate funds exhibits some striking similarities to the banking sector. Spillover risk (where problems from one bank can spread to others within the system) is a primary concern for authorities and a rationale for regulating the financial system. For example, Aharony and Swary (1983) find that large bank failures can lead to falling prices for solvent bank stocks if the failures are caused by systemwide banking problems. Bannier et al. (2008) state in their study about German open-end real estate funds that the closure of a fund and the subsequent "fire sales" of real estate assets may significantly influence the overall market for these real estate assets. Open-end real estate funds predominantely had a very similiar investment strategy. Therefore, other funds may 
be forced to adjust their current net asset value due to falling market prices, which would be a sign for negative spillover effects. Furthermore, as several fund's portfolios exhibit a comparable asset class and regional diversification, the closure of one fund may lead to significant capital outflows from other funds, since retail investors compare the different funds, besides other fundamentals, and decide to sell their shares at net asset value.

In our context of already distressed real estate funds, negative spillover effects may arise from the announcement of another fund's closure or liquidation. Such an announcement by other funds may increase doubts over the future development of the overall asset class. Investors in distressed real estate funds who speculated on a successful reopening may see their hopes vanish with the announcement of another fund's suspensions of share redemptions. Similarly, the announcement of another distressed real estate fund entering the liquidation phase may imply that the last chance for a successful reopening has passed. As a result of negative industry news, the share prices of distressed funds may fall even further, thereby increasing the discount to NAV. This leads us to Hypothesis 4:

Hypothesis 4: The discount to NAV increases due to negative spillover effects from the announcement of other fund's closures or liquidations.

\section{Sentiment}

Our next hypothesis aiming to explain the systematic component of NAV discounts relates to industrywide or macroeconomic sentiment. In particular, we focus on variables that proxy for industrywide sentiment toward the asset class. If investor sentiment reflects investor behavior toward an asset class, we expect there to be an effect on the returns of the underlying securities. The returns on the secondary market may then directly impact a widening or a compression of the discount to NAV.

Indro (2004) finds a high correlation between aggregate equity fund flows and other measures of investor sentiment, such as the bullishness of individual investors or newsletter writers. This suggests that fund flows can be a useful proxy for investor sentiment. Consistent with the hypothesis that investor sentiment affects returns, Warther (1995) finds a strong relationship between aggregate flows into equity mutual funds and contemporaneous returns of the securities held by these funds. Similarly, Ben-Rephael et al. (2012) find that monthly aggregate shifts between bond funds and equity funds are positively correlated with contemporaneous aggregate stock market excess returns.

In addition to industry-specific sentiment, the returns and NAV discounts of distressed real estate funds may also be driven by macroeconomic sentiment. Two popular uncertainty indices are used commonly in the literature. First, the Economic Policy Uncertainty Index of Baker et al. (2015) features prominently in a plethora of research (e.g., European Central Bank, 2013, European Commission, 2013, and International Monetary Fund, 2014). ${ }^{12}$ Second, the implied volatility index (VIX), which proxies for stock market uncertainty, measures anticipated (implied) stock market risk based on the difference between stock prices and stock price futures (e.g., Baker et al., 2015; Bekaert et al., 2013). This measure is important because the funds are subject to common stock market risk after the event of closing. The expected impact of sentiment on the discount to NAV of distressed funds is summarized in Hypothesis 5:

Hypothesis 5: Negative sentiment regarding the asset class, the capital markets in general, and the overall economy all increase the discount to NAV.

\footnotetext{
12 The full list can be found at: www.policyuncertainty.com/research.
} 


\title{
Data, Methodology and Sample Description
}

\author{
Data Sources
}

Our sample consists of nine distressed German open-end real estate funds. Table 1 provides an overview of the funds, as well as their closure, reopening, and liquidation dates.

Our panel dataset covers the October 2008 through June 2016 period. The starting point coincides with the closure of the nine funds. Subsequently, substantial divergences between secondary market prices and NAVs emerged, which led to the NAV spreads examined in this paper.

Following Lee et al. (1991) and Barkham and Ward (1999), we calculate the discount to NAV as the difference between the NAV and the fund's contemporary market price divided by the NAV. NAVs are calculated and published on a daily basis. This approach does not change for distressed funds, i.e. there is no structural discontinuity. Market prices are provided by the Hamburg-Hannover stock exchange. ${ }^{13}$

Our fund-specific variables are hand-collected from the monthly fact sheets found on the individual fund websites, as well as from fund's semiannual and annual reports. We always incorporate any new information as soon as it becomes available to the market. Those variables which are reported only semiannually, remain constant for 6 months, but still represent the most current data available. An alternative would be to run our regressions only at a semi-annual (or even annual) frequency. This would imply that we would not employ the new information that becomes available with the monthly reports, but that is available to the market. For this reason, we choose to analyze our data on a monthly basis. It is important to note that several funds are managed by depository banks that no longer provide monthly fact sheets. Their annual and semiannual reports are also less detailed. Even though our explanatory variables are somewhat less up-to-date toward the end of the sample, we still incorporate any fund specific information as soon as it becomes available to the market.

The share of institutional owners per fund comes from Morningstar. We also collect industrywide data on fund flows from the German Investment and Asset Management Association (BVI), which collects data about net flows directly from its members, who represent the vast majority of the German mutual fund industry. This variable includes the monthly net flows of 48 public and semi-institutional German open-end real estate funds in our sample period. ${ }^{14}$ Data on GDP come from the OECD.

Research Design and Definition of Variables

We use a panel regression model to examine the determinants of NAV discounts for distressed real estate funds. Our panel consists of 708 fund-month observations. The key vari-

\footnotetext{
13 Shares of German open-end funds trade on all major German stock exchanges (Frankfurt, Berlin, Düsseldorf, Hamburg, Munich, Stuttgart), except for Xetra. The NAV discounts calculated in this paper are based on closing share prices from the Hamburg stock exchange. Hamburg stock exchange was the first exchange that introduced the trading of investment funds in 2002. Until today, Hamburg is clearly the leading exchange for open-end real estate fund shares as measured by trading volume, enabling it to provide the highest liquidity.

14 According to an order of the German Central Bank in 2013 extraordinary payouts of distressed funds have to be considered as capital outflows (BVI, 2016). In contrast, we do not consider extraordinary payouts of distressed funds as capital outflows in order to distinguish between real capital outflows and inflows, as an indicator of investor sentiment.
} 
able of interest is the discount to NAV of fund $i$ at the end of month $t$, which is calculated as follows:

$$
\text { Discount to } N A V_{i, t}=\frac{\text { Stock market price }}{i, t}-1
$$

For the purpose of our empirical tests, we estimate the following panel regression model:

$$
\begin{aligned}
& \text { Discount to } N A V_{i, t}=\alpha+\beta_{1} \Delta \text { Leverage }_{i, t-1}+\beta_{2} \Delta \text { Liquidity }_{i, t-1}+\beta_{3} \Delta T E R_{i, t-1} \\
& +\beta_{4} \text { Extraordinary Payouts } s_{i, t}
\end{aligned}
$$

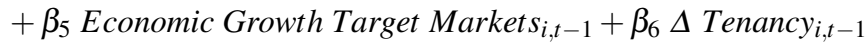

$$
\begin{aligned}
& +\beta_{7} \text { Flows Asset Class }_{t}+\beta_{8} \text { Event Fund Liquidation }_{t} \\
& +\beta_{9} \text { Event Fund Closure }_{t} \\
& +\beta_{10} \text { Policy Uncertainty Index Europe }{ }_{t}+\beta_{11} \text { VIX Europe } \text { E }_{t} \\
& +\beta_{12} \Delta \text { Perform }_{i, t-1}+\beta_{13} \Delta \text { Fund Size }_{i, t-1} \\
& +\beta_{14} \Delta \text { Institutional }_{i, t-1}+\beta_{15} \text { Fund Reopening }_{i, t} \\
& +v_{i, t}
\end{aligned}
$$

Our explanatory variables are defined as follows:

Leverage is the leverage ratio of the fund, calculated at the fund level as the ratio between loans taken out and the total fund size.

Liquidity is the liquidity ratio, measured as the ratio of the fund's cash equivalents to total fund size.

$T E R$ represents annual management costs as a percentage of fund size. Because investors can no longer "vote with their feet", we expect to find higher fees associated with higher NAV discounts.

Extraordinary payouts are defined as total fund-specific payouts in a given month relative to a fund's NAV. Similarly to the TER ratio, this variable aims to capture the degree of investor friendliness of a fund's management. A negative correlation between this variable and the discount to NAV would indicate a lower degree of conflicts of interest between investors and fund managers, leading to a smaller NAV discount.

Economic Growth Target Markets is a fund-specific GDP growth measure. This variable aims to capture the anticipated price development of a fund's real estate portfolio. It is calculated as the weighted sum of monthly GDP growth in a fund's target markets.

Tenancy represents the proportion of rented to overall space of a real estate fund's assets. This variable is used to proxy for a fund's portfolio quality. As with the previous variable, which captures the GDP development of a fund's underlying property markets, a higher portfolio quality or better outlook is expected to lead to a smaller discount to NAV.

Event Fund Closure is a 0/1 indicator variable that captures the announcement that at least one other real estate fund has suspended share redemptions.

Event Fund Liquidation is a dummy variable that indicates another fund is unable to reopen and has begun the liquidation process. Both events may lead to a deterioration in investor sentiment. A positive relationship between these events and the discount to NAV would generally confirm the spillover hypothesis. We also include closure or liquidation announcements from semi-institutional funds.

Flows Asset Class are the total net fund flows (newly bought fund shares less redemptions) into all healthy open-end real estate funds in billion Euro. Here, we also include flows 
into semi-institutional funds. While only normally functioning open-end real estate funds can have net flows, we use this variable to capture general investor sentiment toward the asset class.

Policy Uncertainty Index Europe aims to capture the degree of political uncertainty in Europe. To construct this Index, Baker et al. (2015) first select two influential newspapers for each European country, such as, e.g., "Le Mond" and "Le Figaro" for France, or "Handelsblatt" and "Frankfurter Allgemeine Zeitung" for Germany. Next, the authors count the number of articles that include the terms "uncertain", "uncertainty", "economic", or "economy", and at least one policy-relevant item. The count is scaled by the overall number of articles in each newspaper.

VIX Europe is the Euro Stoxx 50 Volatility Index (VSTOXX), commonly referred to as VIX. This is our second measure of macroeconomic uncertainty. This index measures the anticipated (implied) stock market risk based on the difference between stock prices and stock price futures. Both macroeconomic indices are normalized (i.e., the mean was subtracted, and all values subsequently divided by their standard deviations). This transformation allows us to not only interpret the sign and statistical significance of the respective regression coefficients, but also to compare the magnitudes of both coefficients. Our set of control variables consists of a fund's past performance, fund size, and share of institutional owners, as well as a dummy variable indicating whether the distressed real estate fund of interest already experienced a suspension of share redemptions and subsequent reopening.

Performance is the appraisal-based rolling twelve-month performance according to BVI. This variable basically reflects the NAV performance. On the one hand, high returns are indicative of solid fund performance. On the other hand, they may signal that the fund has not yet adjusted its appraisal values to reflect lower market values following the financial crisis. This would imply that the NAV per share is expected to fall in the future, thereby justifying a larger discount. Downs et. al (2016a) find that fund investors in German openend real estate funds invest predominantely in funds which performed well in the past, which therefore obtain higher capital inflows. Additional demand for fund shares due to positive past performance could also have a diminishing effect on the discount to NAV of distressed German open-end real estate funds.

Fund Size is measured in billions of Euros. The Federal Financial Supervisory Authority (BaFin) of Germany determines an individual liquidation horizon for each fund. Larger funds tend to receive more time to liquidate their portfolio (up to five years) compared to smaller ones (up to three years). Therefore, on the one hand, fund size could be interpreted as a proxy for expected liquidation time. Hence, we would expect a positive relationship between fund size and NAV discounts. On the other hand, larger funds with longer liquidation horizons might use an optimized market timing strategy for their property disposals, and could enjoy better bargaining positions. Moreover, Fecht and Wedow (2014) find that larger German open-end real estate funds experience less capital outflows in times of fund crises. Since fund's capital outflows can be viewed as a measure of investors sentiment, larger fund size may also lower discounts to NAV on the secondary market.

Institutional shareholders represents the share of institutional shareholders as provided by Morningstar. Here, too, the expected effect is ambivalent. German open-end real estate funds are predominantly held by retail investors. Thus, due to their low price volatility and relatively high and stable yields compared to money market interest rates, conventional wisdom suggests that institutional investors exploited open-end funds as a cash substitute prior to the fund crisis. We use the share of institutional ownership to test whether it has an effect on the discount to NAV. Once open-end real estate funds become distressed, their share prices on the secondary market show substantial price volatility. Therefore, investors are 
likely to reevaluate their optimal risk exposure towards the asset class, and could potentially decide to sell their shares. This could lead to further price pressure on the secondary market, and hence larger discounts to NAV. Consistent with this idea, Larrain et al. (2017) examine the effect of a regulatory constraint, which forced pension funds to fire sale their Chilean stock holdings. The authors find that those stocks with the highest selling pressure lost $4 \%$ compared to other stocks. Alternatively, a large percentage of well-informed institutional investors may signal a high fund quality, and could be associated with lower discounts to NAV. Evidence in the related literature is mixed. Barclay et al. (1993) find that closed-end funds with large blockholders display larger discounts. In contrast, Morri and Benedetto (2009) find that Italian closed-end real estate funds with large blockholders tend to exhibit smaller discounts to NAV. For German open-end real estate funds, Fecht and Wedow (2014) find that a lower share of institutional investors significantly lower capital outflows.

Fund Reopening is a dummy variable that indicates whether a distressed real estate fund has already reopened previously, and hence suspended share redemptions for a second time. Investors may perceive such funds as less likely to achieve another reopening, thus leading to larger discounts to NAV.

Our fund-specific variables generally enter the regression model with one lag, because the monthly fact sheets are published with a time lag. Also, investors need time to adjust their decision making process subsequent to changes in key fund indicators. However, we include extraordinary payouts, net capital inflows, dummy variables, and uncertainty indicators without any lag. Extraordinary Payouts, the closure or liquidation of one or more specific open-end real estate funds, is generally a comprehensive event that would be extensively reported in the media. Therefore, we would expect both institutional and private investors to recognize the significance of such an event, and adjust their investment strategies within one month. Moreover, uncertainty is a prevalent condition. In addition to the economic interpretation, the statistical significance of the coefficients, as well as the overall fitness measures like the AIC criteria, support the chosen lag structure as explained above.

In order for the effects to have a causal interpretation, we predominantly use lagged explanatory variables, which is generally considered to mitigate endogeneity issues. Regarding our non-lagged variables, the VIX and the political uncertainty index are clearly not affected by price or NAV. Hence, potential reverse causation issues are limited to the variables event fund liquidation, event fund closure, flows asset class, and extraordinary payouts. Fund liquidation and fund closure are industry-wide event dummy variables, which are by definition external to the fund under consideration. It seems unlikely that the NAV discount of a specific fund would drive industry-wide fund liquidations or closures. The same argument applies to fund flows into the whole asset class, which are measured only for the subsample of non-distressed funds. Extraordinary payouts are probably the only variable where a reverse causation issue may exist: As a fund pays out cash to its investors, the NAV per share falls exactly by the payout per share. On the other hand, the stock market price per share should also fall by a very similar amount. The process is comparable to dividend payments of common stocks. As a part of Hypothesis 2, we argue why the stock price may fall somewhat less than the NAV per share. If investors honor the shareholder friendly policy of instant cash distributions, the discount to NAV would decrease as a result of a positive share price response.

Due to the non-stationarity of the leverage ratio, the liquidity ratio, TER, the tenancy rate, performance, fund size, and the share of institutional investors, these variables enter the regression with their first differences $(\Delta)$. 
Descriptive Statistics

Table 2 shows some descriptive statistics on the dependent and explanatory variables, and shows that the average discount to NAV of distressed real estate funds is $25 \%$ with a standard deviation of $13.3 \%$.

The independent variables in Table 2 are separated into three categories: fund-specific, external variables, and control variables. The average leverage ratio of all funds is $24.8 \%$. Figure 4 shows that the average leverage ratio diminishes considerably over time. This effect is to be expected, because funds repay their loans from the proceeds from property disposals. There is also a substantial heterogeneity of leverage ratios across funds. The DEGI International fund reports a leverage ratio of $0 \%$ in June 2014, while the Morgan Stanley P2 value fund exhibits a leverage ratio of $69 \%$ at the beginning of 2014 .

The liquidity ratios also show considerable heterogeneity. The TMW Immobilien Weltfonds fund displays a liquidity ratio of $0.3 \%$ in May 2016, which is below the regulatory threshold of $5.0 \%$ and is allowed for only a short period of time. However, this fund exhibits a very low liquidity ratio throughout the entire sample period. In contrast, the UBS 3 Sector Real Estate fund has a liquidity ratio of $21.6 \%$ at the closing date, which rises as high as $82.8 \%$ by September 2015 . Note that fund strategies partially cause these substantial differences. During the sample period, the DEGI International fund liquidated a significant portion of its assets without substantial extraordinary payouts until October 2014. On average, the liquidity ratio amounts to about $20.0 \%$. Figure 4 illustrates a considerable increase in average liquidity ratios over time due to high sales proceeds beginning in Q3 2012.

The average total expense ratio is $0.9 \%$. The KanAm Grundinvest fund has the highest management fees at the end of the sample period in 2016 with 1.5\%, while the AXA Immoselect exhibits the lowest fees with $0.3 \%$ in October 2008.

The average payout ratio is only $1.2 \%$. The UBS 3 Sector Real Estate fund made an extraordinary payment of about $56.5 \%$ of its respective net asset value in December 2015. Other funds distributed their payouts more evenly over the sample period, however, the management of AXA Immoselect fund continuously distributed about 3\%-4\% of its respective net asset value value per share from 2008 through 2013. Figure 4 illustrates a significant increase in extraordinary payouts due to the accelerating liquidation process, which began in Q3 2012.

The average GDP growth rate of the fund's target markets is $0.1 \%$ and ranges from $-3.1 \%$ to $+1.3 \%$. While there is little heterogeneity across funds regarding this measure, Figure 4 shows a substantial time variation that is attributable to the economic rebound following the global financial crisis.

The average tenancy rate is $89.3 \%$. Table 2 shows that the Morgan Stanley P2 Value exhibited a tenancy rate of $100 \%$ over the June-December 2013 period, while the TMW Immobilien Weltfonds fund reported only $69 \%$ to $76 \%$ during the same period.

On average, a closure or a liquidation occurred in $12.9 \%$ of the periods. Consistent with the spillover hypothesis, Figure 4 shows that closures and liquidations tend to cluster together over time.

The average asset class capital inflows are EUR 215 million per month. The funds experienced strong capital inflows of about EUR 1.69 billion in January 2010, and rather extreme capital outflows of EUR 4.36 billion in October 2008.

Figure 4 shows that the implied stock market volatility, as measured by VIX Europe, tends to decline over time. In contrast, the Political Uncertainty Index increases during the middle of our sample period, when many funds entered the liquidation phase. 
Table 3 shows a positive correlation on an aggregate level between the absolute level of the NAV discount and the European Policy Uncertainty Index (general uncertainty) of (+0.36). However, we observe an inverse relationship between the absolute level of the discount to NAV and the VIX (stock market uncertainty) of -0.45 . Although both uncertainty indices share two peaks, in 2008 (global financial crisis) and 2012 (European debt crisis), they appear uncorrelated in general.

The rolling twelve-month performance of the funds (based on NAVs) averages $-4.5 \%$, and ranges from $-38.9 \%$ to $+8.6 \%$. Just as with the overall economic development, the variance of this variable is driven mainly by the time dimension, namely, the global financial crisis.

Fund size ranges from EUR 69 million to EUR 6.6 billion. The UBS 3 Sector Real Estate fund is the smallest fund, with an average size over the entire sample period of EUR 321.0 million. The CS Euroreal fund is the largest, with an average of EUR 5.0 billion. Despite the negative time trend, the time dimension explains only a small part of the overall variance of the fund size variable. Institutional shareholders on average represent $11.1 \%$ of all fund investors. The UBS 3 Sector Real Estate fund reports an institutional share of up to $37 \%$, while the DEGI Europa never exceeds more than $5 \%$.

According to Table 3 , the discount to NAV shows a relatively strong negative correlation with fund size (-0.25) and fund performance (-0.56). Furthermore, the NAV discount shows a relatively strong positive correlation with the share of institutional investors $(0.35)$.

\section{Results}

Table 4 contains the panel regression results, which are estimated using time fixed effects, as well as heteroscedasticity-robust standard errors. ${ }^{15}$ Model I employs only fund-specific explanatory variables, which are used to test Hypotheses 1-3. The control variables, used in all models, are also fund-specific. In models II and III, we subsequently introduce further explanatory variables that are external to the funds. Model II includes two industry-wide variables, which enables us to test the spillover hypothesis (Hypothesis 4). Finally, model III also incorporates macroeconomic variables in order to test Hypothesis 5. Our initial analysis focuses on the impact of a fund's financial leverage on its discount to NAV. Consistent with Hypothesis 1, we find that the discount to NAV increases with the leverage ratio. An increase by one percentage point leads on average to a $0.089 \%$ larger discount to NAV in the next period. Mirroring this principle, the liquidity ratio has a negative effect on the discount to NAV. A rise in the lagged liquidity ratio by one percentage point leads on average to a $0.139 \%$ lower discount to NAV. This is plausible, given that a larger share of cash and short-term money market positions represents save money for fund investors. Therefore, larger liquidity ratios diminish uncertainty, which is primarily related to the appraisal values of the real estate portion of the fund. In summary, both of our proxies are consistent with Hypothesis 1 . The discount to NAV is driven by a funds financial leverage, since it increases (decreases) with its leverage (liquidity) ratio.

Next, we examine whether NAV discounts are related to potential conflicts of interest between fund management and investors. We find no significant influence of management costs (TER) on the NAV discount. Extraordinary payouts, on the other hand, play an important role. A $1 \%$ higher payout leads on average to a $0.273 \%$ lower discount. This result is

\footnotetext{
15 Time-fixed effects enable us to control for any unobserved time effects. However, the time dummies also cause identical regression coefficients for the fund-specific variables across all three specifications. In the next chapter, we describe a method to analyze the goodness of fit for each specification.
} 
consistent with Hypothesis 2. When a fund's management regularly pays out high amounts of liquidity, rather than holding cash or properties to maximize their fee income, this signals investor friendliness. The practice of extraordinary payouts at time of closing, however, differs considerably among funds in the dataset. Some closed funds pay out substantial distributions on a regular basis, while others exhibit an irregular payout pattern. Others pay more irregularly or infrequently. A history of regular distributions increases trust in fund's management, and thereby reducing the discount to NAV.

To test Hypothesis 3, we use two variables that proxy for a fund's portfolio quality. First, real estate funds are more likely to be able to sell assets for reasonable prices in goodperforming countries than in countries locked in recession. Investors are informed about the target market mix on a monhtly basis. Moreover, investors receive continuous information about economic developments via the media. Both sources of information should theoretically lead to higher demand on the secondary market for funds invested in more prosperous markets. Nevertheless, we find no significant influence of the economic growth variable on the discount to NAV.

Our second proxy for fund's portfolio quality is the average tenancy rate. All else being equal, higher quality properties should be associated with larger tenancy rates, and vice versa. However, the coefficient on the tenancy rate is not statistically significantly different from zero. ${ }^{16}$ Hence, we find no evidence for Hypothesis 3, i.e., NAV discounts do not appear to be driven by a fund's portfolio quality. A possible explanation for this result could be that a fund's portfolio quality is already sufficiently reflected in its NAV. Hence, investors would not need an additional risk premium, and this would be reflected in lower share prices.

Our regression results in model II provide strong support for the spillover hypothesis (H3). In case another distressed real estate fund fails to reopen and subsequently announces liquidation, the discount to NAV for all distressed funds rises on average by $0.249 \%$. This effect remains significant, although somewhat weaker, in model III, when further external variables are included in the regression model. The announcement of other fund liquidations may lead to diminished hope, and is likely to further deteriorate investor trust in this asset class. The announcement of other fund closures, on the other hand, does not appear to significantly impact the NAV discount. ${ }^{17}$

We use three proxy variables to test whether NAV discounts are driven by investor sentiment. First, we use capital inflows into all open-end real estate funds to examine the impact of investor sentiment toward the specific asset class on NAV discounts. Model III documents a significant relationship between asset class net flows and the discount to NAV. Larger fund flows into the overall asset class on average diminish the discount to NAV. Second, we use the European Policy Uncertainty index, which measures overall macroeconomic uncertainty. An increase in this index leads on average to a larger NAV discount. In contrast, when we use the VIX to measure specific stock market risk, we find no significant relation between

\footnotetext{
16 As a robustness check we examine the impact of the share of lease terms ending in the short, mid, and long term as an additional proxy for the portfolio quality. However, none of these variables had a significant impact on the discount to NAV. The results are available from the authors upon request.

17 Moreover, we examine potential spillover effects on funds that are not distressed. In particular we examine the relationship between the total fund flows into all non-distressed open-end funds and closure or liquidation announcements of distressed funds. In untabulated results we calculate the correlation coefficients between our contemporaneous and lagged spillover variables and all asset class fund flows into non-distressed funds. While most correlation coefficients show the expected negative sign, only the correlation between fund closure announcements and fund flows in the same period is statistically significant at the 5\%-level with a correlation coefficient of -0.34
} 
the VIX Europe and the NAV discount. ${ }^{18}$ In conclusion, we find evidence for Hypothesis 5, when our proxy for investor sentiment is based on fund flows and political uncertainty. The uncertainty on the stock market has no significant effect.

Regarding our control variables, we find a positive relationship between the share of institutional investors and the discount to NAV. An increase of the share of institutional investors by one percentage point leads on average to a $0.478 \%$ larger discount in the next period. Past performance, fund size, and the dummy variable indicating a former fund closure are all statistically insignificant.

At the request of an anonymous referee, we also examine whether the discount is driven by changes in price or NAV. We address this question empirically, by running simple regressions of changes in the NAV discount on changes (\%) of price and/or NAV. The univariate regression results for models 1 and 2 show that both variables are highly significant. However, the R-squareds are rather low in both cases with 5.1\% (model 1) and 9.4\% (model 2). The R-squared increases to $50 \%$ when both variables are included simultaneously (model 3 ). We conclude that the NAV spread is driven by both, changes in price and changes in NAV. ${ }^{19}$

The land transfer tax has to be paid for all German real estate assets in the fund's portfolio in case the fund management is transferred to a depository bank. The transfer implies by law the selling off of the entire portfolio, which results in a 3.5\%-6.5\% transfer tax ("Grunderwerbssteuer") depending on the federal state, where the particular property is registered. Since, fund investors are aware of this additional tax burden at the end of the liquidation period, the imminent tax-costs should increase the discount to NAV beginning with fund closure. Moreover, the effect on the discount to NAV may increase near the end of the determined liquidation period, especially if there are several German properties left to sell. Therefore, we include the share of German real estate assets, the time left for liquidation in months as stated before and a dummy variable indicating when the fund management is transferred to the depository bank into our regression model. We additionally include all three variables separately and together to our main regression model (III). Individually added, the share of German properties shows a positive but not significant sign. Moreover, the variable indicating the time left until the liquidation date has also an increasing effect on discount to NAV. Nevertheless the variable is also not significant. Adding the dummy variable indicating the transfer to the depository, we find a negative and significant sign. The completed transfer to the depository bank lowers the discount to NAV. This result is surprising, since the transfer implies the payment of the above mentioned additional tax. Nevertheless, the fund managements form provisions starting with the particular fund closure event. A decreasing effect of the management transfer to the depository bank on discount to NAV may arise if these formed provisions prove to be adequate and, therefore, lower the uncertainty about the liquidation process for current fund investors. Including all three variables together in our main model, we do not find any significant effect on discount to NAV. These regression results are tabulated in Table A1 in the appendix. In untabulated results, we also control for the legal fund environment, e.g., the selling restrictions of the real estate properties. We find no significant influence of these variables on the discount to NAV. We also find no significant influence of regional or sectoral diversification (Herfindahl index) on the discount to NAV.

In order to determine the goodness of fit of our models, we use the time dummy coefficients of the three model specifications (I-III). Because the dummy variables have no eco-

\footnotetext{
18 In untabulated results, we find a positive relationship between the VIX Europe and discounts to NAV when we run the regression without the Policy Uncertainty Index.

19 The regression results are available from the author upon request.
} 
nomic interpretation, we consider the coefficients to be the unexplained, yet time-specific, components of the discount to NAV. Figure 5 illustrates how the unexplained (unsystematic) time effects diminish after we incorporate additional time-dependent variables into the model. The figure shows the progression of the time dummy coefficients over 90 periods from January 2009 to June 2016 (93 periods in total, minus three periods for the lag structure). The time dummy coefficients of model I exhibit considerably positive signs over time. Moreover, the parabolic progression indicates a time trend that we can account for by using the monthly time dummies in the regression model. This parabolic progression can also be seen in the development of the discount to NAV, which increases after the individual closure dates for each fund to a maximum in mid-2012, and significantly decreases thereafter by about 20\%-30\% until June 2016. Model II exhibits a less distinct time trend. Model III, which includes all variables, has the best fit and, therefore, the least distinct time trend of the dummy regression coefficients.

\section{The Performance of Distressed Real Estate Funds as a Function of the Discount to NAV}

In this section we analyze the performance of distressed open-end real estate funds as a function of the discount to NAV to address the question of whether investors are better off selling their funds on the secondary market at a discount or waiting for liquidation. ${ }^{20}$ First, we examine the performance of all distressed real estate funds over the sample period. Figure 6 shows the capital-weighted total return index for all distressed real estate funds. The implicit assumption is that any distributions are directly reinvested into all distressed real estate funds according to their respective market capitalization. This approach reflects the experience of the average fund investor, who reinvested distributions into the same asset class. Figure 6 reveals that, on average, investors in distressed real estate funds had to suffer strong losses over the sample period. Until the end of the sample period, investors lost about $26 \%$, as the total return index stands at ca. 0.74 in June 2016. Most of the losses, however, occurred between 2010 and 2013, where investors lost up to 44\% (as of August 2013) of their initially invested capital. Unsurprisingly, this point coincides with the highest average NAV discount over the sample period. From the end of 2013 to mid 2015, distressed real estate funds posted strong returns, due to falling NAV discounts. Overall, Figure 6 suggests that NAV discounts had been too large, retrospectively. In particular, periods with average NAV discounts of more than $30 \%$ were followed by a strong positive performance of distressed real estate funds.

Next, we analyze the performance of individual distressed real estate funds as a function of their discount to NAV. Table 5 shows the average annualized returns of individual funds as a function of their NAV discount at the beginning of the period. For this analysis, we divide our funds into six groups according to their NAV discounts. The average performance of all groups with NAV discounts below $30 \%$ is negative on average. However, the group of funds with NAV discounts of 30-40\% obtained annualized returns of $2.95 \%$ on average over the following month, which seems acceptable given the low interest rate environment over the sample period. Funds with NAV discounts of $40-50 \%$ obtain returns of $3.61 \%$ and funds with discounts of more than $50 \%$ obtain very strong gains of $27.41 \%$ on average. However, it should be noted that the number of observations in this group is only 29 . Overall, the results are broadly in line with Figure 6, and confirm that the break-even point for investors to hold or sell their shares is around a discount to NAV of $30 \%$. Finally, we also examine whether

\footnotetext{
20 We thank an anonymous referee for drawing our attention to this important question.
} 
investors can exploit potential mispricings across distressed funds in a given period through an active trading strategy. Woltering et al. (2018) examine an active value investing strategy based on global REITs and REOCs and document positive risk-adjusted returns for the portfolio of global REITs and REOCs with the highest discounts to NAV. Similarly, we examine whether investors are better off investing in the subsample of distressed real estate funds with the highest discounts to NAV. Due to the small sample size, we only build two portfolios. The high-discount portfolio represents the $50 \%$ of stocks with the highest discount to NAV at any given point of time, whereas the low-discount portfolio represents the other half of expensive distressed funds, as measured by their NAV discount. The underlying idea is that an active investor, for example a hedge fund, reweights the portfolio at the end of every month to exploit potential mispricings if the discounts are unjustifiably high, in the hope that they correct over the following period. Figure 7 shows the total return indices for both portfolios, whereby the blue line represents the high-discount portfolio, which we expect to outperform. While the performance of both portfolios is rather similar over the first half of the sample period, the high discount portfolio clearly outperforms the low discount portfolio between 2012 and 2016. The cumulative outperformance of the high discount portfolio is approximately $35 \%$ at the end of the sample period. This finding suggests that the NAV dispersion across funds is too high and can be exploited by an arbitrage strategy.

In summary, our findings reveal that investors should not sell their shares if the NAV discount is larger than $30 \%$. Furthermore, investors should consider the relative pricing of their fund shares. If a fund's shares trade at a large discount relative to its peers, it may be wise to hold the shares even if the discount is less than $30 \%$. Finally, at least over our sample period, the cross-sectional variation of NAV discounts was too high and investors were able to reap arbitrage gains by actively investing in the funds with the highest NAV discounts, while avoiding those with the lowest NAV discounts.

\section{Conclusion}

This paper examines the discount to NAV of German open-end real estate funds in the aftermath of the financial crisis. When German open-end real estate funds become unable to maintain the guarantee to buy back shares from investors at the NAV, investors can only sell their shares on the secondary market at a discount to NAV unless they are willing to await the complete fund liquidation. Germany represents the largest market for open-end real estate funds worldwide. For this reason, the German experience is a highly relevant case study for all market participants of countries with open-end fund regimes, and for regulators of those countries which are considering to introduce them.

First of all, our paper contributes to the growing literature on open-end real estate funds. By examining NAV discounts, we effectively answer the question how open-end funds are priced relative to their NAV when their price is determined by supply and demand on the secondary market. We find that funds with more leverage are associated with higher NAV discounts. In contrast, funds with high liquidity ratios and those with high payouts ratios obtain lower NAV discounts. As these variables are under control of the fund management, our results suggest that fund managers of distressed funds have some room to minimize the harm of their investors. Our empirical framework also enables investors or fund managers to calculate predicted NAV discounts. Such a stress test may complement risk management strategies.

On the other hand, we find that NAV discounts are also driven by factors which are out of fund management's control. For example, NAV discounts increase following the liqui- 
dation announcements of other funds. Furthermore, we document that NAV discounts are driven by investor sentiment, as they are related to asset class fund flows and the degree of macroeconomic uncertainty. As these variables are unrelated to the underlying asset value of the funds, our findings suggest that distressed real estate funds are not necessarily priced efficiently on the secondary market.

In additional analyses we examine the relationship between the returns of distressed real estate funds and the discount to NAV in a univariate setting. We find that the breakeven point of buying vs. holding shares of distressed funds is around a discount to NAV of $30 \%$. NAV discounts of more than $30 \%$ appear excessive as they are associated with large positive subsequent returns, whereas NAV discounts below $30 \%$ are on average associated with negative returns. The analysis of the cross section of fund returns support the notion that distressed real estate funds are not priced efficiently. We find that the portfolio of funds with the highest NAV discounts clearly outperforms the portfolio of distressed funds with the lowest NAV discounts. These findings are highly relevant for existing as well as potential investors in distressed real estate funds.

While our results are based on the German open-end real estate fund industry, they should be generalizable at least for all countries with similar liquidation regimes. However, we believe that our results may be even transferrable to real estate funds in a broader sense. Besides listed real estate and open-end real estate funds, (closed-end) private equity real estate funds are the third major real investment vehicle worldwide. Investors in real estate private equity are typically locked into their investment over the fund's lifetime of 15-20 years. However, many investors choose to sell their fund's shares before the fund's natural liquidation date. In this case they must find a buyer and typically have to sell their shares at a considerable discount to NAV. Effectively, this means that real estate fund shares with a clear path towards liquidation are traded on the secondary market, which is a setting that mirrors the one in this paper. One potential application of our study is the calculation of predicted NAV discounts. In this sense, our empirical framework may also be helpful in pricing secondary market transactions for private equity real estate fund shares.

Finally, our research also contributes to the broad literature on NAV discounts in real estate. Prior studies examine NAV discounts of REITs and REOCs and are either based on average NAV estimates by analysts or on book values of equity. The latter approach only makes sense as long as the properties are regularly reappraised, so the book value is based on fair values and not on historical costs. In contrast, the NAVs in our study are based on the highest standards possible, as they form the basis of actual transaction prices during normal times. As a consequence, the dependent variable in our study is less likely to suffer from measurement errors. Another difference is that the funds in our sample are actually being liquidated over the foreseeable future. Hence, investors in distressed real estate funds can expect any unjustified NAV discount to be dissolved over the fund liquidation horizon, whereas the discount to NAV of REITs and REOCs can theoretically persist forever. Besides studying NAV discounts in this unique setting, we contribute to the literature on NAV discounts by identifying two new impact factors: potential spillover effects from the announcement of other fund liquidations, and the influence of macroeconomic uncertainty proxied by the Policy Uncertainty Index. 


\section{References}

Aharony J. \& Swary, I. (1983). Contagion Effects of Bank Failures: Evidence from Capital Markets. Journal of Business, 56(3), 305-322.

Baker, S., Bloom, N. \& Davis, S. (2015). Measuring Economic Policy Uncertainty. Discussion Paper: Centre for Economic Performance (CEP), No. 1379.

Bannier, C., Fecht, F. \& Tyrell, M. (2008). Open-end real estate funds in Germany - Genesis and crisis. Kredit und Kapital, 41(1), 9-36.

Barclay, M. ,Holderness, C. \& Pontiff, J. (1993). Private benefits from block ownership and discounts on closed-end funds. Journal of Financial Economics, 33, 263-291.

Barkham, R. \& Ward, C. (1999). Investor Sentiment and Noise Traders. Journal of Real Estate Research, 18(2), 291-312.

Bekaert, G., Hoerova, M. \& Lo Duca, M. (2013). Risk, Uncertainty and Monetary Policy. Journal of Monetary Economics, 60(7), 771-788.

Ben-Rephael, A., Kandel, S. \& Wohl, A. (2012). Measuring investor sentiment with mutual fund flows. Journal of Financial Economics, 104(2), 363-382.

Bond, S. \& Shilling, J. (2004). An evaluation of property company discounts in Europe. Unpublished working paper, EPRA, University of Cambridge.

Brounen, D. \&ter Laak, M. (2005). Understanding the discount: Evidence from European property shares. Journal of Real Estate Portfolio Management, 11(3), 241-252.

Chay, J. \& Trzcinka, C. (1999). Managerial performance and the cross-sectional pricing of closed-end funds. Journal of Financial Economics, 52(3), 379-408.

Cherkes, M. (2003). A positive theory of closed-end funds as an investment vehicle. EFA 2004, Maastricht Meetings Paper, No. 1317.

De Wit, I. \& van Dijk, R. (2003). The Global Determinants of Direct Office Real Estate Returns. Journal of Real Estate Finance and Economics, 26(1), 27-45.

Downs, D., Sebastian, S., Weistroffer, C. \& Woltering, R.-O. (2016a). Real Estate Fund Flows and the Flow-Performance Relationship. Journal of Real Estate Finance and Economics,52(4), 347-382.

Downs, D., Sebastian, S. \& Woltering, R.-O. (2016b). Real Estate Fund Openings and Cannibalization. Real Estate Economics (in print), DOI 10.1111/1540-6229.12144, 1-39.

Fecht, F. \& Wedow, M. (2014). The dark and the bright side of liquidity risks: Evidence from open-end real estate funds in Germany. Journal of Financial Intermediation, 23(3), 376-399.

Gemmill, G. \& Thomas, D. (2002). Noise Trading, Costly Arbitrage and Asset Prices: Evidence from Closed-end Funds. Journal of Finance, 47(6), 2571-2594.

Indro, D. (2004). Does Mutual Fund Flow Reflect Investor Sentiment?.Journal of Behavioral Finance, 5(2), 105-115.

Larrain, B., Munoz, D. \& Tessad, J. (2017). Asset fire sales in equity markets: Evidence from a quasi-natural experiment, Journal of Financial Intermediation, 30(1), 71-85.

Lee, C. ,Shleifer, A. \& Thaler, R. (1991). Investor Sentiment and the Closed-End Fund Puzzle. Journal of Finance, 46(1), 75-109.

Lenkey, S. (2015). The closed-end fund puzzle: Management fees and private information. Journal of Financial Intermediation, 24(1), 112-129. 
Malkiel, B. \& Xu, Y. (2005). The Persistence and Predictability of Closed-End Fund Discounts. SSRN Electronic Journal.

Morri, G. \& Benedetto, P. (2009). Leverage and NAV discount: Evidence from Italian real estate investment funds. Journal of European Real Estate Research, 2(1), 33-55.

Patel, K., Pereira, R. \& Zavodov, K. (2009). Mean-Reversion in REITs Discount to NAV \& Risk Premium. Journal of Real Estate Finance and Economics, 39(3), 229-247.

Pontiff, J. (1996). Costly Arbitrage: Evidence from Closed-End Funds. Quarterly Journal of Economics, 111(4), 1135-1151.

Schnejdar, S., Heinrich, M., Woltering, R.-O. \& Sebastian, S. (2018). The Determinants of Real Estate Fund Closures. SSRN, working paper, https : //ssrn. com/abstract=3236569.

Schweizer, D., Hass, L. Johanning, L. \& Rudolph, B. (2013). Do Alternative Real Estate Investment Vehicles Add Value to REITs? Evidence from German Open-ended Property Funds. Journal of Real Estate Finance and Economics, 47(1), 65-82.

Warther, V. (1995). Aggregate mutual fund flows and security returns. Journal of Financial Economics, 39(2), 209-235.

Weistroffer, C. \& Sebastian, S. (2015). The German Open-End Fund Crisis - A Valuation Problem?. Journal of Real Estate Finance and Economics, 50(4), 517-548.

Woltering, R.-O., Weis, C., Schindler, F. \& Sebastian, S. (2018). Capturing the Value Premium - Global Evidence from a Fair Value-Based Investment Strategy. Journal of Banking and Finance, 86, 53-69.

Wurtzebach, C., Mueller, G. \& Machi, D. (1991). The Impact of Inflation and Vacancy of Real Estate Returns. Journal of Real Estate Research, 6(2), 153-168. 


\section{Figures}

Fig. 1: Total Fund Size (based on NAVs) and Total Market Capitalization

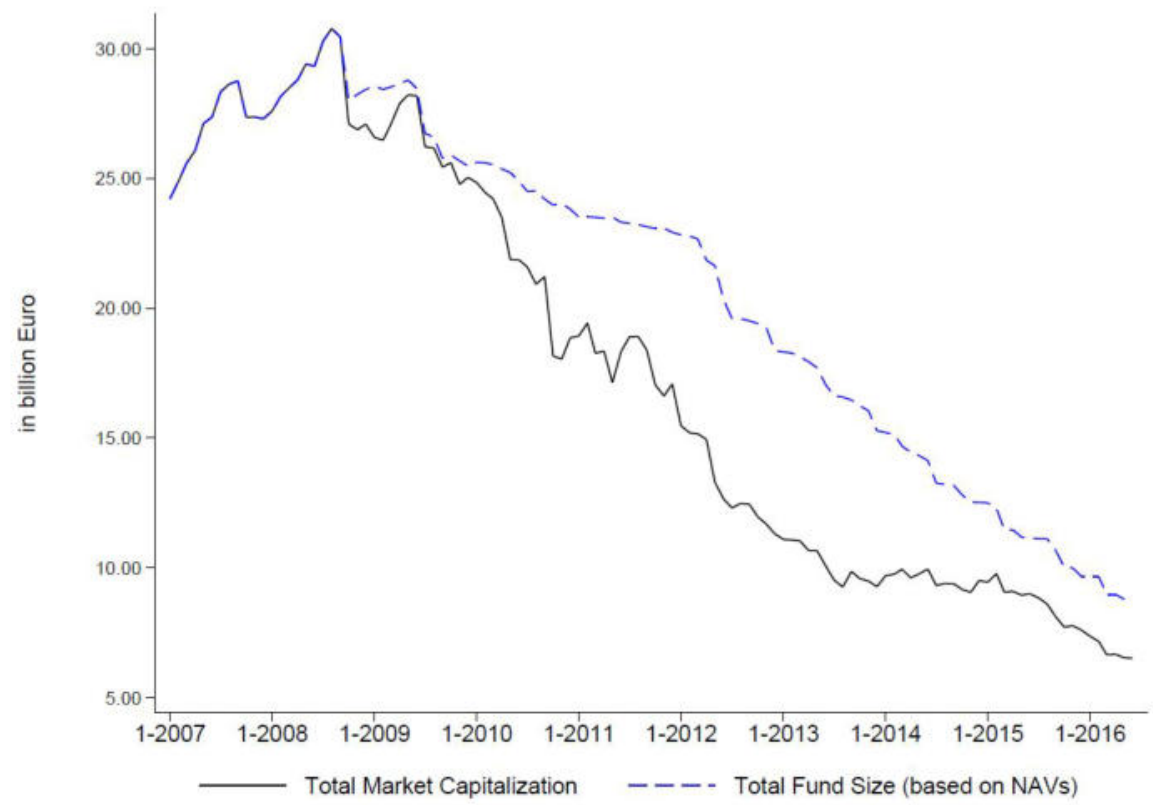

This figure shows the total Fund Size (based on NAVs)and total market capitalization of all distressed open-end real estate funds from 2007:1 to 2016:6. The above figure illustrates the absolute deviation between NAV and market prices. Total market capitalization is defined as the sum of the fund-specific stock market prices weighted by the total number of shares of each fund. Total Fund Size (based on NAVs) is calculated as the sum of the total number of fund shares multiplied by the NAV of each fund. 
Fig. 2: Discount to NAV

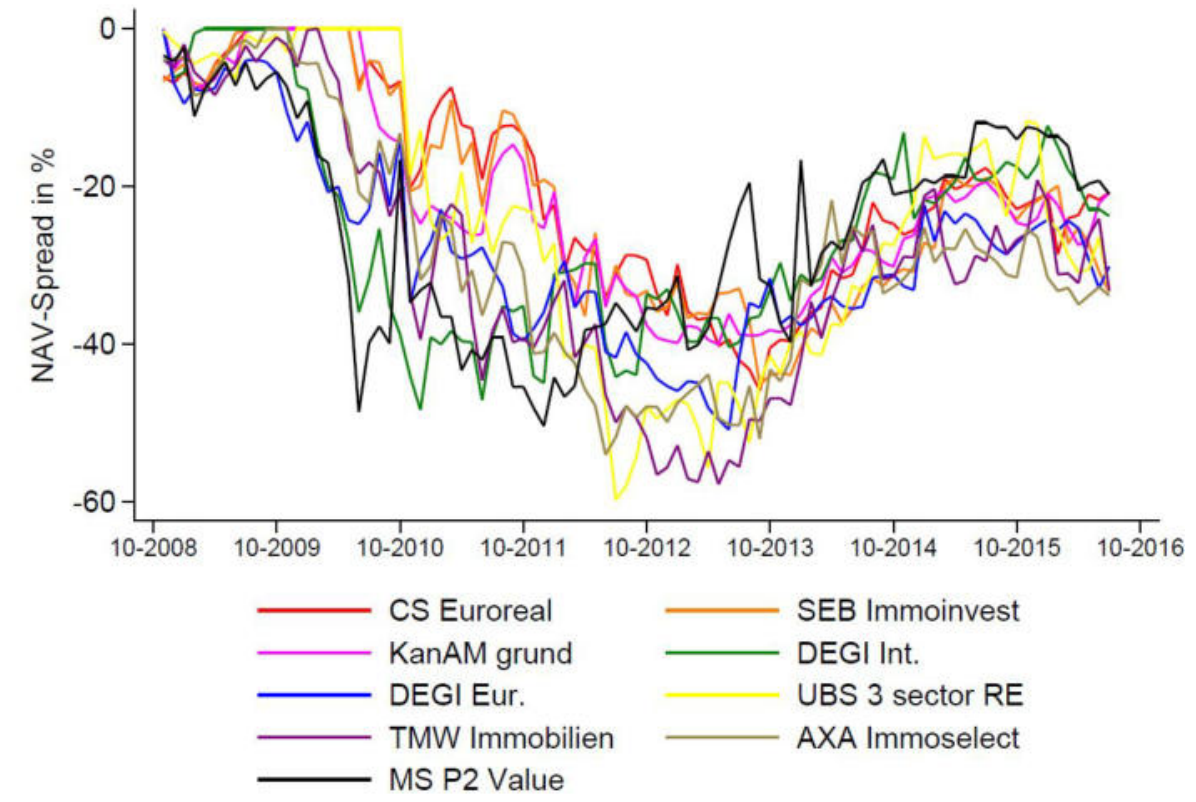

This figure shows the development of the discount to NAV for each fund from 2007:1 to 2016:6. The discount to NAV indicates the negative deviation between the funds NAV and the secondary market price in percent. 
Fig. 3: Overview Open-Ended Fund Crisis

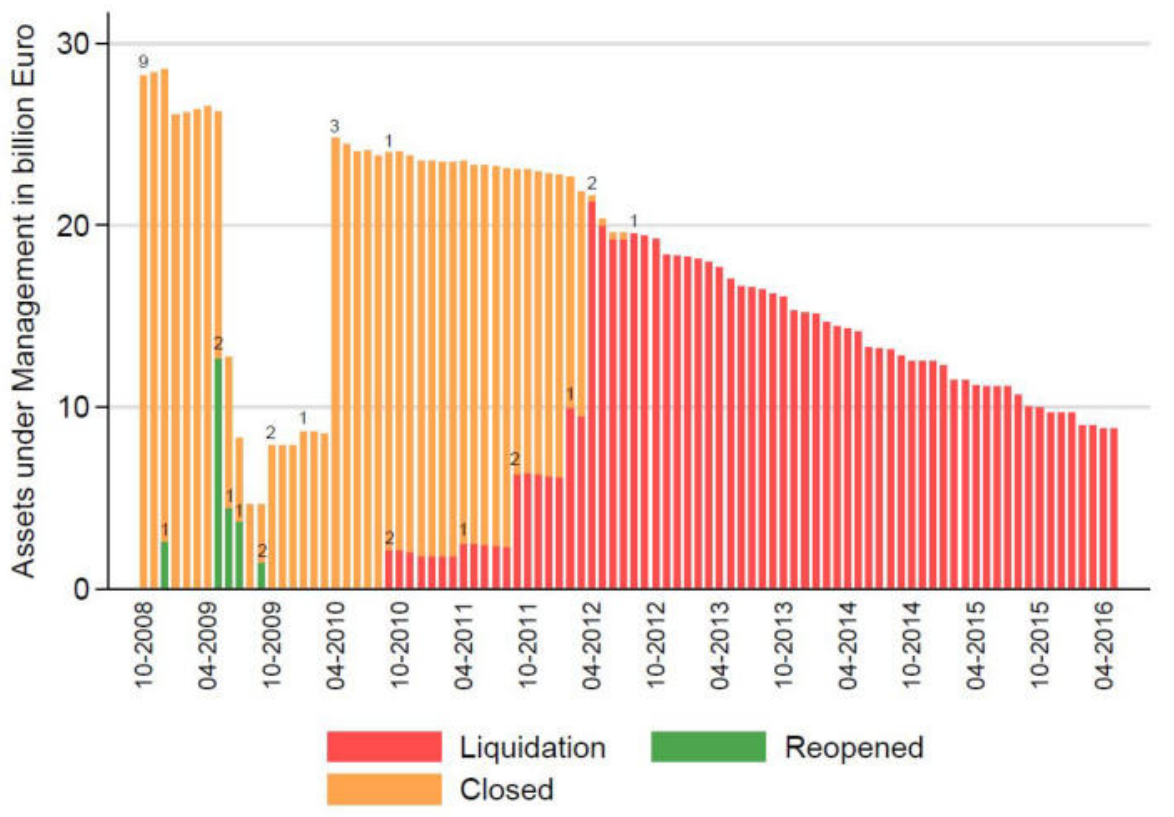

This figure shows the number and the total fund size of the German open-end real estate funds, that either suspended share redemptions (orange bars) or were in the process of fund liquidation (red bars). The graph also shows the number and the total fund size of any reopenings (green bars). 
Fig. 4: Discount to NAV, Fund Specifics, External and Control Variables

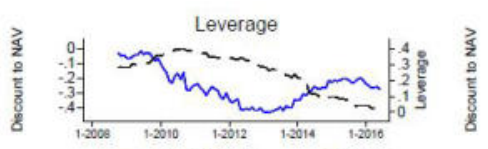

- Discount to NAV - - Leverage

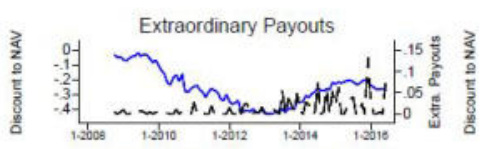

- Discount to Nay - - Etrat Paons

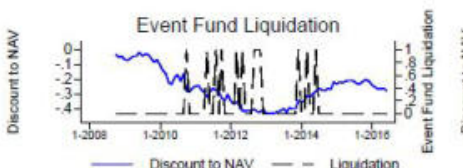

- Discount to NAV - - Liquidation

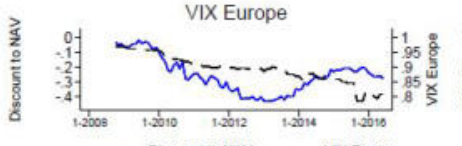

- Discount to NaV - - VIX Europe

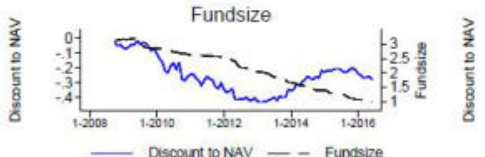

This figure illustrates the average progression of the fund-specific, external and control variables for all distressed real estat funds in contrast to the average course of the discount to NAV from 2008:10 to 2016:6. The first two rows show the development of the fund-specific factors. The third row shows the three industry-wide spillover variables. The fourth row includes the two macroeconomic uncertainty indicators. The control variables are displayed afterwards.

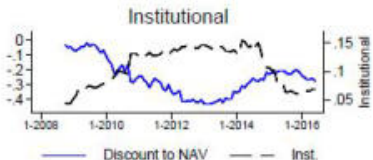

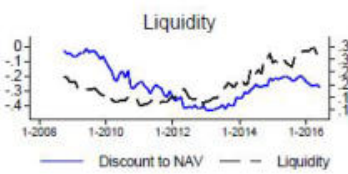
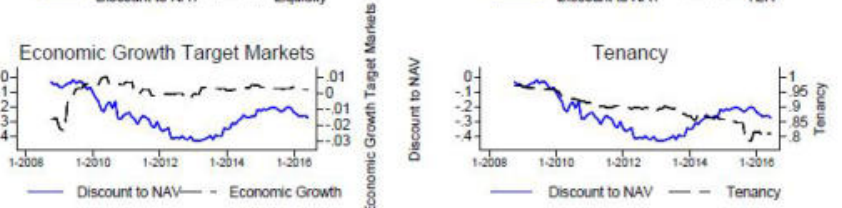

- Discount to Nav - - Tenancy

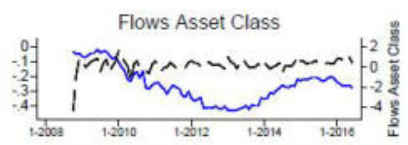

- Discount to NAV - - Flows Asset Cass

- Discount to NAV - - Closure

Policy Uncertainty Index Europe
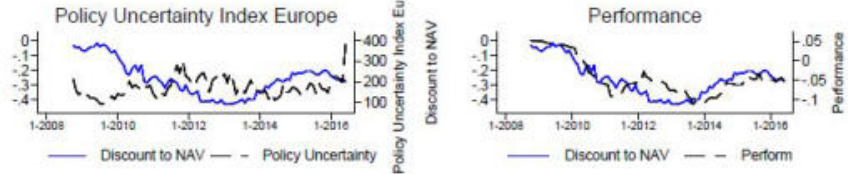
Fig. 5: Development of Time Dummies

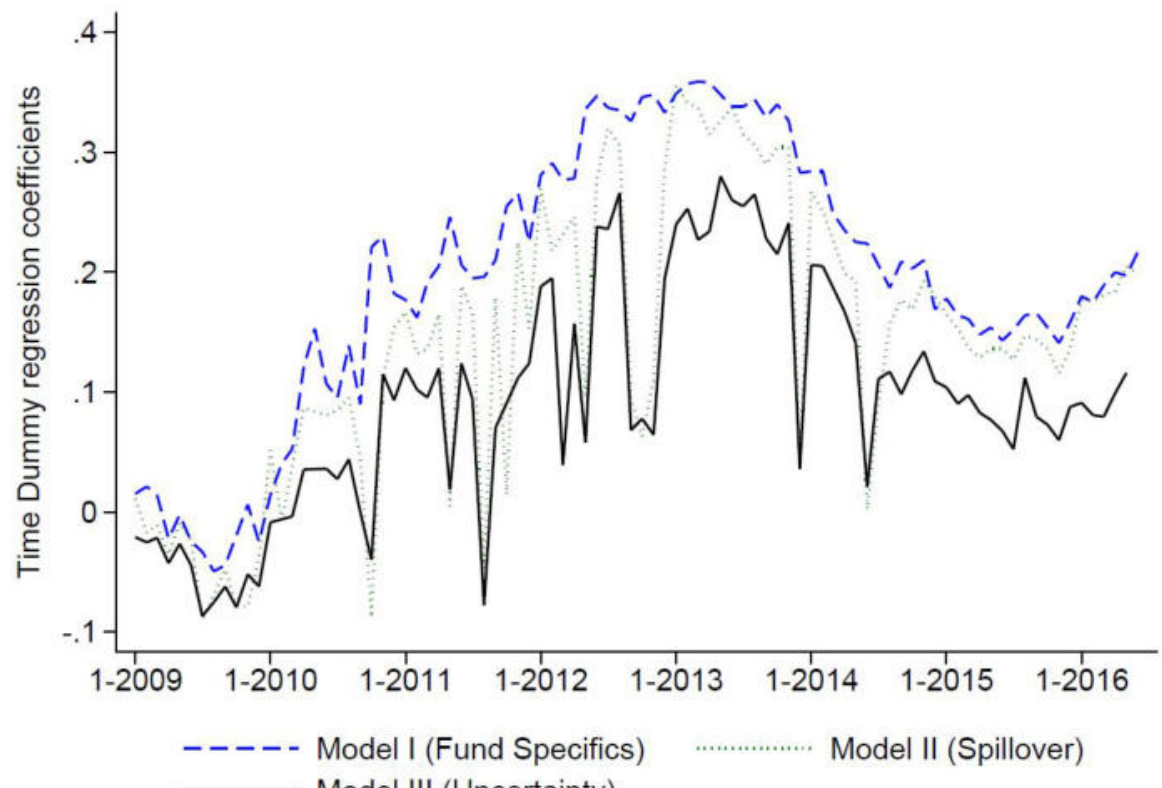

This figure shows the regression coefficients of the time dummies for the ninety periods from January 2009 through June 2016 (note there is a loss of three periods at the beginning due to the preferred lag structure). The regression coefficients of these dummy variables represent the unexplained but time-specific component of the discount to NAV. The progression of each line near zero indicates a better fit of the model compared to the other model specifications, as there is less unexplained variance left. 
Fig. 6: Capital-weighted total return index for all distressed real estate funds

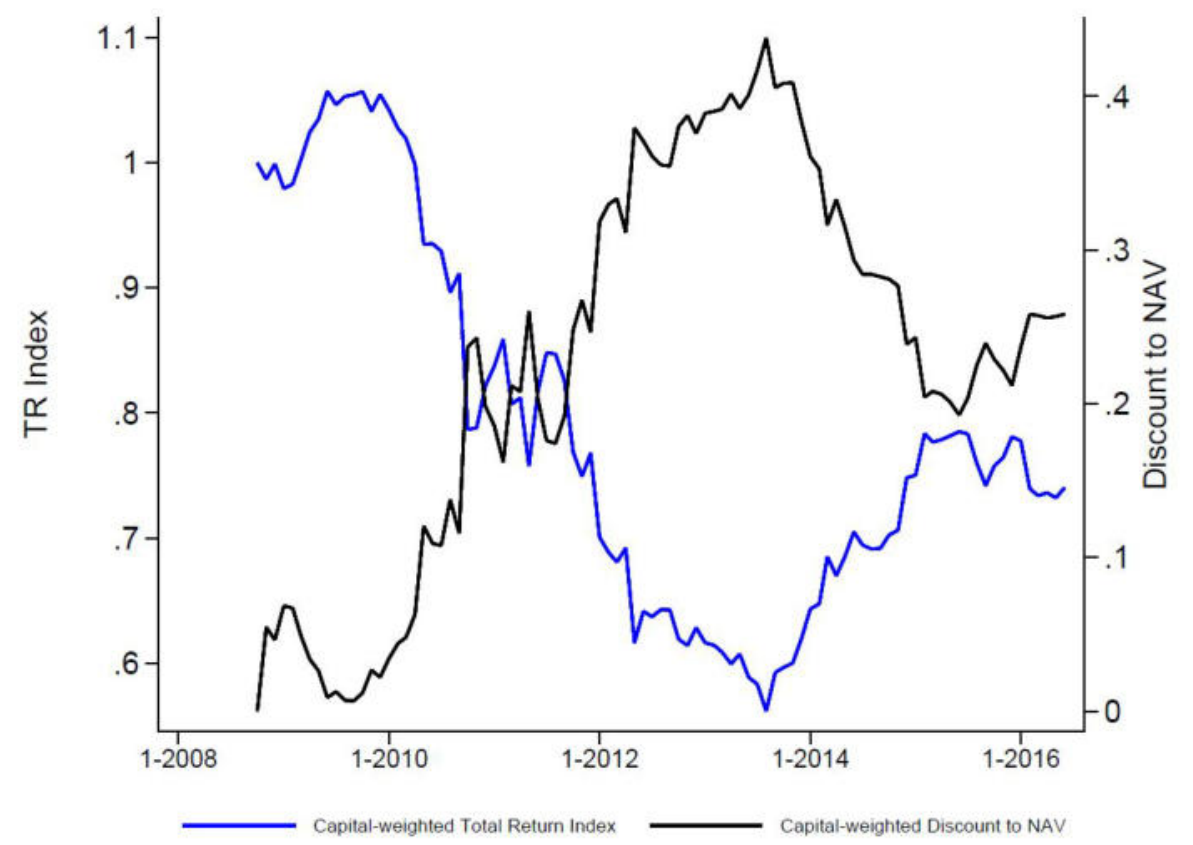

This figure shows the capital-weighted total return index of distressed open-end real estate funds (blue line) and the capital-weighted discount to NAV of all distressed funds. 
Fig. 7: Total Return Indices of Low vs. High Discount to NAV Portfolios

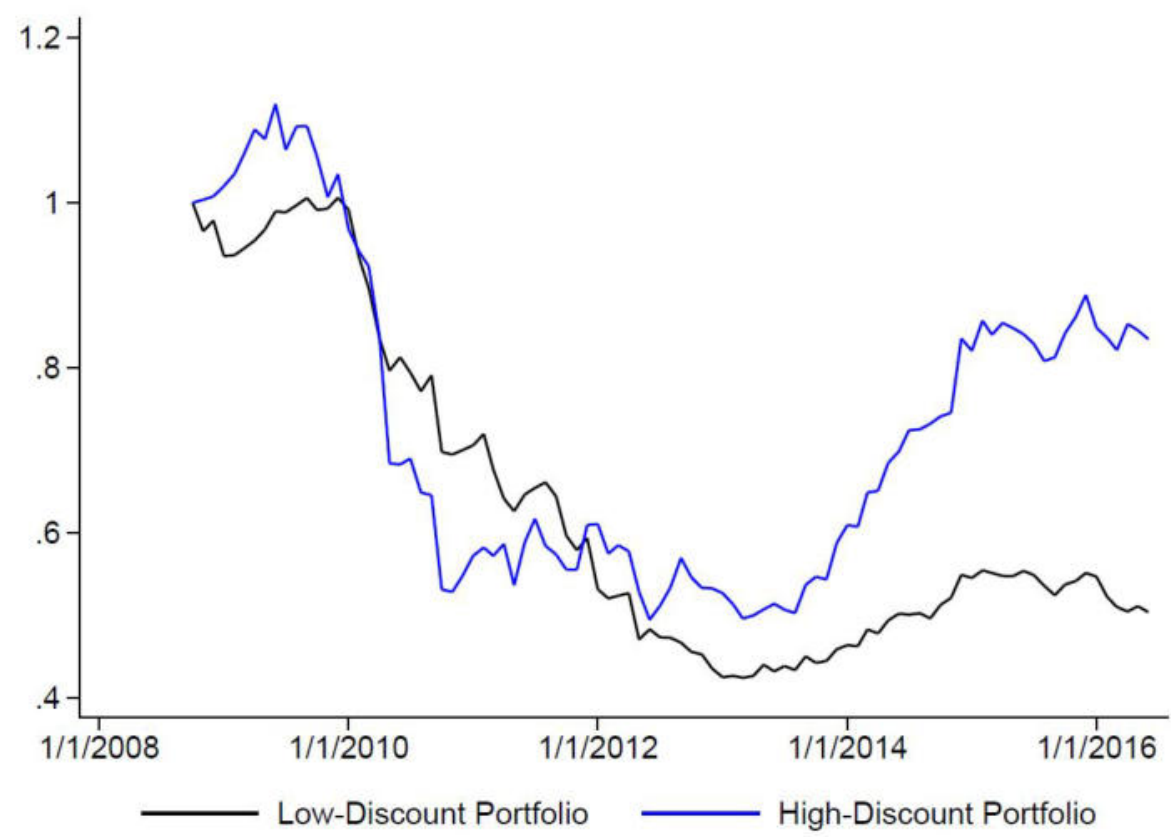

This figure shows the total return indices for the portfolio of low (black line) and high (blue line) discount to NAV portfolios. At the beginning of each month we sort all distressed funds according to their discount to NAV and build two portfolios for which we observe the returns over the month. The low discount portfolio is comprised of the $50 \%$ of distressed funds with the lowest discount to NAV. The high discount portfolio is comprised of the $50 \%$ of distressed funds with the highest discounts to NAV. 
Tables

Table 1: Overview of Distressed Open-End Real Estate Funds

\begin{tabular}{lcccc}
\hline fund & first closure & second closure & notice liquidation & depository bank \\
\hline CS Euroreal A & $10 / 30 / 08-06 / 29 / 09$ & $05 / 20 / 10$ & $05 / 21 / 12$ & $04 / 30 / 17$ \\
SEBImmoInvest & $10 / 29 / 08-06 / 02 / 09$ & $05 / 06 / 10$ & $05 / 07 / 12$ & $04 / 30 / 17$ \\
KanAmGrundinvest & $10 / 28 / 08-07 / 08 / 09$ & $05 / 06 / 10$ & $03 / 01 / 12$ & $12 / 31 / 16$ \\
AXAImmoselect & $10 / 28 / 08-08 / 28 / 09$ & $11 / 19 / 09$ & $10 / 20 / 11$ & $10 / 20 / 14$ \\
DEGI International & $10 / 31 / 08-01 / 31 / 09$ & $11 / 17 / 09$ & $10 / 25 / 11$ & $10 / 15 / 14$ \\
DEGI Europa & - & $10 / 31 / 08$ & $10 / 01 / 10$ & $09 / 30 / 13$ \\
UBS (D) 3 Sector RE & $10 / 31 / 08-10 / 31 / 09$ & $10 / 06 / 10$ & $09 / 05 / 12$ & $09 / 05 / 15$ \\
TMWImmobilien & $10 / 28 / 08-10 / 31 / 09$ & $02 / 08 / 10$ & $05 / 31 / 11$ & $05 / 31 / 14$ \\
Morgan Stanley P2 Value & - & $10 / 30 / 08$ & $10 / 26 / 10$ & $09 / 30 / 13$ \\
\hline
\end{tabular}

This table provides an overview of the relevant events for all distressed public open-end real estate funds, particularly date of first closure, reopening date, date of their second closure, date of liquidation announcement, and date of the depository bank taking control of the liquidation process. 
Table 2: Overview Summary Statistics

\begin{tabular}{lccccc}
\hline & Mean & Std.Dev. & Min & Max & Obs \\
\hline Discount to NAV & 0.267 & 0.133 & 0.000 & 0.598 & 783 \\
Fund Specific Variables & & & & & \\
Leverage & 0.248 & 0.157 & 0.000 & 0.690 & 837 \\
Liquidity & 0.200 & 0.142 & 0.003 & 0.828 & 837 \\
TER & 0.009 & 0.002 & 0.003 & 0.015 & 837 \\
Extraordinary Payouts & 0.012 & 0.05 & 0.000 & 0.565 & 837 \\
Economic Growth Target Markets & 0.001 & 0.006 & -0.031 & 0.013 & 836 \\
Tenancy & 0.893 & 0.077 & 0.595 & 1.000 & 815 \\
External Variables & & & & & \\
Event Fund Liquidation & 0.129 & 0.335 & 0.000 & 1.000 & 837 \\
Event Fund Closure & 0.129 & 0.335 & 0.000 & 1.000 & 837 \\
Flows Asset Class & 0.215 & 0.651 & -4.358 & 1.693 & 837 \\
Policy Uncertainty Index Europe & 174.315 & 47.613 & 91.379 & 394.635 & 837 \\
VIX Europe & 26.400 & 8.832 & 14.392 & 60.677 & 837 \\
Control Variables & & & & & \\
Perform & -0.045 & 0.086 & -0.389 & 0.086 & 816 \\
Fund Size & 2.140 & 1.970 & 0.069 & 6.598 & 837 \\
Institutional & 0.111 & 0.092 & 0.003 & 0.368 & 792 \\
Fund Reopening & 0.671 & 0.470 & 0.000 & 1.000 & 837 \\
\hline
\end{tabular}

This table provides an overview of the mean, standard deviation, minimum, maximum, and the number of observations for all variables. 


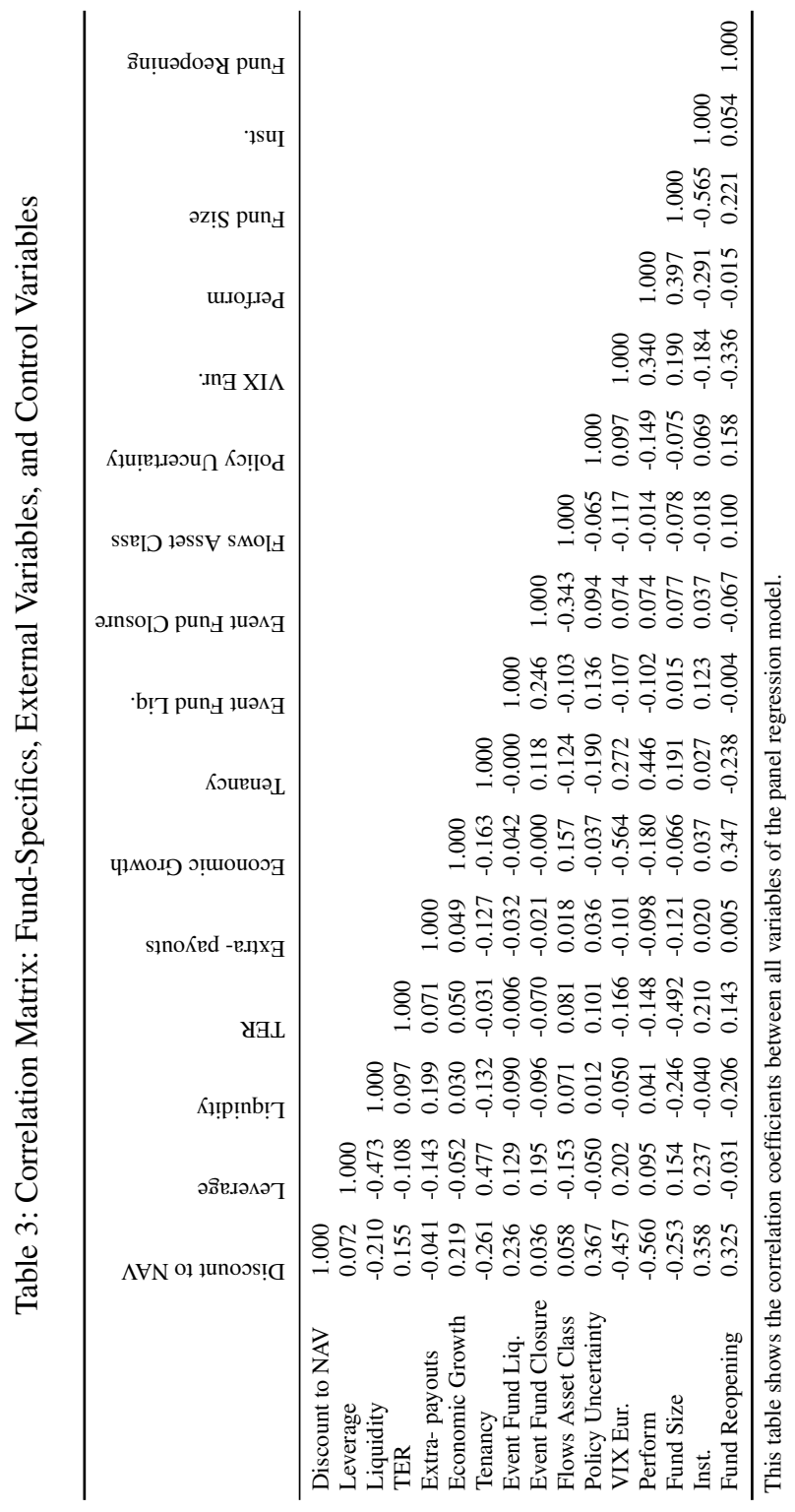


Table 4: Explaining the Discount to NAV

\begin{tabular}{|c|c|c|c|}
\hline & (I) & (II) & (III) \\
\hline \multicolumn{4}{|l|}{ Fund Specific Variables } \\
\hline$\Delta$ Leverage $_{i, t-1}$ & $\begin{array}{l}0.0898^{*} \\
(0.0475)\end{array}$ & $\begin{array}{l}0.0898^{*} \\
(0.0475)\end{array}$ & $\begin{array}{l}0.0898 * \\
(0.0475)\end{array}$ \\
\hline$\Delta$ Liquidit $_{i, t-1}$ & $\begin{array}{l}-0.139 * * \\
(0.0588)\end{array}$ & $\begin{array}{l}-0.139 * * \\
(0.0588)\end{array}$ & $\begin{array}{l}-0.139 * * \\
(0.0588)\end{array}$ \\
\hline$\Delta T E R_{i, t-1}$ & $\begin{array}{l}-1.702 \\
(5.059)\end{array}$ & $\begin{array}{l}-1.702 \\
(5.059)\end{array}$ & $\begin{array}{l}-1.702 \\
(5.059)\end{array}$ \\
\hline Extraordinary Payouts $_{i, t}$ & $\begin{array}{l}-0.273^{* * *} \\
(0.0643)\end{array}$ & $\begin{array}{c}-0.273 * * * \\
(0.0643)\end{array}$ & $\begin{array}{c}-0.273 * * * \\
(0.0643)\end{array}$ \\
\hline Economic Growth Target Markets $s_{i, t-1}$ & $\begin{array}{c}0.193 \\
(1.936)\end{array}$ & $\begin{array}{c}0.193 \\
(1.936)\end{array}$ & $\begin{array}{c}0.193 \\
(1.936)\end{array}$ \\
\hline$\Delta$ Tenancy $_{i, t-1}$ & $\begin{array}{c}-0.116 \\
(0.0919)\end{array}$ & $\begin{array}{l}-0.116 \\
(0.0919)\end{array}$ & $\begin{array}{c}-0.116 \\
(0.0919)\end{array}$ \\
\hline \multicolumn{4}{|l|}{ External Variables } \\
\hline Event Fund Liquidation $_{i, t}$ & $\begin{array}{l}- \\
-\end{array}$ & $\begin{array}{c}0.249 * * * \\
(0.045)\end{array}$ & $\begin{array}{c}0.148 * * * \\
(0.0343)\end{array}$ \\
\hline Event $F$ und Closure $_{i, t}$ & $\begin{array}{l}- \\
-\end{array}$ & $\begin{array}{c}0.028 \\
(0.034)\end{array}$ & $\begin{array}{l}0.00218 \\
(0.0682)\end{array}$ \\
\hline Flows Asset Class ${ }_{i, t}$ & $\begin{array}{l}- \\
-\end{array}$ & - & $\begin{array}{l}-0.0308 * \\
(0.0142)\end{array}$ \\
\hline Policy Uncertainty Index Europe $e_{i, t}{ }^{*}$ & - & $\begin{array}{l}- \\
-\end{array}$ & $\begin{array}{r}0.0377 * * * \\
(0.00727)\end{array}$ \\
\hline VIX Europe Eut, $^{*}$ & - & $\begin{array}{l}- \\
-\end{array}$ & $\begin{array}{l}-0.0133 \\
(0.0142)\end{array}$ \\
\hline \multicolumn{4}{|l|}{ Control Variables } \\
\hline$\Delta$ Perform $_{i, t-1}$ & $\begin{array}{l}-0.0788 \\
(0.127)\end{array}$ & $\begin{array}{l}-0.0788 \\
(0.127)\end{array}$ & $\begin{array}{l}-0.0788 \\
(0.127)\end{array}$ \\
\hline$\Delta$ Fund Size $i, t-1$ & $\begin{array}{l}0.00239 \\
(0.0377)\end{array}$ & $\begin{array}{l}0.00239 \\
(0.0377)\end{array}$ & $\begin{array}{l}0.00239 \\
(0.0377)\end{array}$ \\
\hline$\Delta$ Institutional $_{i, t-1}$ & $\begin{array}{l}0.478^{* *} \\
(0.167)\end{array}$ & $\begin{array}{c}0.478 * * \\
(0.167)\end{array}$ & $\begin{array}{c}0.478 * * \\
(0.167)\end{array}$ \\
\hline Fund Reopening ${ }_{i, t}$ & $\begin{array}{c}0.0283 \\
(0.0361)\end{array}$ & $\begin{array}{l}0.0283 \\
(0.0361)\end{array}$ & $\begin{array}{c}0.0283 \\
(0.0361)\end{array}$ \\
\hline Constant & $\begin{array}{c}0.0540 * * \\
(0.0198)\end{array}$ & $\begin{array}{c}0.0908^{* * *} \\
(0.0263)\end{array}$ & $\begin{array}{l}0.129 * * \\
(0.0408)\end{array}$ \\
\hline Observations & 708 & 708 & 708 \\
\hline R-squared & 0.735 & 0.735 & 0.735 \\
\hline Number of funds & 9 & 9 & 9 \\
\hline
\end{tabular}

This table shows the fixed-effects panel regression results. Model (I) contains the particular influence of the fund-specific variables. Model (II) adds the industry-wide variables to test the spillover hypothesis. Model (III) is the main model, which also includes industry-wide and macroeconomic proxies for investor sentiment. Policy Uncertainty and VIX Europe Variables are standardized with zero mean and a standard deviation of one. Robust standard errors are in parentheses, $* * * \mathrm{p}<0.01, * * \mathrm{p}<0.05$ and $* \mathrm{p}<0.1$. 
Table 5: Average Performance depending on Discount to NAV

\begin{tabular}{lcccc}
\hline Level of Discount to NAV & 1-month-performance & obs. & 12-month-performance & obs. \\
\hline 0-10\% Discount & $-6,51 \%$ & 118 & $-13,39 \%$ & 118 \\
10-20\% Discount & $-15,54 \%$ & 111 & $-20,24 \%$ & 84 \\
20-30\% Discount & $-7,82 \%$ & 196 & $-10,14 \%$ & 139 \\
30-40\% Discount & $2,95 \%$ & 215 & $1,31 \%$ & 200 \\
40-50\% Discount & $3,61 \%$ & 105 & $4,26 \%$ & 105 \\
>50\% Discount & $27,41 \%$ & 29 & $16,81 \%$ & 29 \\
\hline
\end{tabular}

This table contains the average monthly performance of distressed funds as a function of the NAV discount. We sort the funds into six groups. The 1-month-performance variable is calculated as the average overall monthly total return dependent on the funds level of discount to NAV in the prior month. The 12-month-performance variable accordingly as the average overall 12 month total return. 
Appendix

Table A1: Influence of Land Transfer Tax on Discount to NAV

\begin{tabular}{|c|c|c|c|c|}
\hline & (I) & (II) & (III) & (IV) \\
\hline \multicolumn{5}{|l|}{ Fund Specific Variables } \\
\hline Invest Germany $_{i, t-1}$ & $\begin{array}{c}0.170 \\
(0.104)\end{array}$ & & & $\begin{array}{c}0.104 \\
(0.0916)\end{array}$ \\
\hline Time to $\mathrm{Liq}_{i, t}$ & & $\begin{array}{l}0.0158 \\
(0.154)\end{array}$ & & $\begin{array}{l}-0.0530 \\
(0.148)\end{array}$ \\
\hline Depository Bank $k_{i, t}$ & & & $\begin{array}{l}-0.0637 * \\
(0.0297)\end{array}$ & $\begin{array}{l}-0.0488 \\
(0.0288)\end{array}$ \\
\hline$\Delta$ Leverage $_{i, t-1}$ & $\begin{array}{c}0.0821 \\
(0.0613)\end{array}$ & $\begin{array}{l}0.0905^{*} \\
(0.0447)\end{array}$ & $\begin{array}{c}0.0877 \\
(0.0677)\end{array}$ & $\begin{array}{c}0.0809 \\
(0.0653)\end{array}$ \\
\hline$\Delta$ Liquidity $_{i, t-1}$ & $\begin{array}{c}-0.148^{* *} \\
(0.0594)\end{array}$ & $\begin{array}{l}-0.140^{*} \\
(0.0699)\end{array}$ & $\begin{array}{c}-0.144 * * \\
(0.0483)\end{array}$ & $\begin{array}{l}-0.143 * * \\
(0.0610)\end{array}$ \\
\hline$\Delta T E R_{i, t-1}$ & $\begin{array}{l}-2.701 \\
(5.165)\end{array}$ & $\begin{array}{l}-1.707 \\
(5.055)\end{array}$ & $\begin{array}{c}-0.886 \\
(4.651)\end{array}$ & $\begin{array}{c}-1.671 \\
(5.219)\end{array}$ \\
\hline Extraordinary Payouts $_{i, t}$ & $\begin{array}{c}-0.272 * * * * \\
(0.0732)\end{array}$ & $\begin{array}{c}-0.275 * * * \\
(0.0740)\end{array}$ & $\begin{array}{c}-0.241 * * * \\
(0.0541)\end{array}$ & $\begin{array}{c}-0.241 * * * \\
(0.0669)\end{array}$ \\
\hline Economic Growth Target Markets $_{i, t-1}$ & $\begin{array}{c}-0.334 \\
(1.779)\end{array}$ & $\begin{array}{c}0.205 \\
(2.022)\end{array}$ & $\begin{array}{c}0.251 \\
(1.961)\end{array}$ & $\begin{array}{c}-0.124 \\
(1.974)\end{array}$ \\
\hline$\Delta$ Tenancy $_{i, t-1}$ & $\begin{array}{c}-0.168 \\
(0.0979)\end{array}$ & $\begin{array}{c}-0.117 \\
(0.0910)\end{array}$ & $\begin{array}{c}-0.114 \\
(0.0978)\end{array}$ & $\begin{array}{c}-0.142 \\
(0.0865)\end{array}$ \\
\hline \multicolumn{5}{|l|}{ External Variables } \\
\hline Event $F$ und Liquidation $_{i, t}$ & $\begin{array}{c}0.153 * * * \\
(0.0343)\end{array}$ & $\begin{array}{c}0.142 * * * \\
(0.0212)\end{array}$ & $\begin{array}{c}0.140 * * * \\
(0.0291)\end{array}$ & $\begin{array}{c}0.148^{* * * *} \\
(0.0191)\end{array}$ \\
\hline Event $^{F}$ und Closure $_{i, t}$ & $\begin{array}{l}0.00753 \\
(0.0626)\end{array}$ & $\begin{array}{c}0.0720 \\
(0.0713)\end{array}$ & $\begin{array}{l}-0.0399 \\
(0.0616)\end{array}$ & $\begin{array}{c}0.0155 \\
(0.0731)\end{array}$ \\
\hline Flows Asset Class $i, t$ & $\begin{array}{l}-0.0311^{*} \\
(0.0139)\end{array}$ & $\begin{array}{l}-0.0455 \\
(0.0768)\end{array}$ & $\begin{array}{c}-0.0346 * * \\
(0.0141)\end{array}$ & $\begin{array}{c}-0.104 \\
(0.0711)\end{array}$ \\
\hline Policy Uncertainty Index Europe $e_{i, t}{ }^{*}$ & $\begin{array}{c}0.0426 * * * \\
(0.00794)\end{array}$ & $\begin{array}{c}0.0316 * * \\
(0.0135)\end{array}$ & $\begin{array}{c}0.0375^{* * * *} * \\
(0.00723)\end{array}$ & $\begin{array}{c}0.0421^{* *} \\
(0.0136)\end{array}$ \\
\hline VIX Europe E $_{i, t} *$ & $\begin{array}{l}-0.0180 \\
(0.0151)\end{array}$ & $\begin{array}{c}-0.0142 \\
(0.0331)\end{array}$ & $\begin{array}{c}-0.0272^{*} \\
(0.0135)\end{array}$ & $\begin{array}{c}-0.0333 \\
(0.0346)\end{array}$ \\
\hline \multicolumn{5}{|l|}{ Control Variables } \\
\hline$\Delta$ Perform $_{i, t-1}$ & $\begin{array}{c}-0.0722 \\
(0.121)\end{array}$ & $\begin{array}{c}-0.0786 \\
(0.127)\end{array}$ & $\begin{array}{l}-0.0617 \\
(0.123)\end{array}$ & $\begin{array}{l}-0.0624 \\
(0.120)\end{array}$ \\
\hline$\Delta$ Fund Size $e_{i, t-1}$ & $\begin{array}{c}0.0147 \\
(0.0354)\end{array}$ & $\begin{array}{l}0.00220 \\
(0.0381)\end{array}$ & $\begin{array}{c}0.0189 \\
(0.0300)\end{array}$ & $\begin{array}{c}0.0232 \\
(0.0310)\end{array}$ \\
\hline$\Delta$ Institutional $_{i, t-1}$ & $\begin{array}{c}0.542 * * \\
(0.176)\end{array}$ & $\begin{array}{c}0.478 * * \\
(0.167)\end{array}$ & $\begin{array}{c}0.537 * * \\
(0.185)\end{array}$ & $\begin{array}{c}0.561 * * \\
(0.185)\end{array}$ \\
\hline Fund Reopening ${ }_{i, t}$ & $\begin{array}{l}0.00821 \\
(0.0422)\end{array}$ & $\begin{array}{c}0.0302 \\
(0.0444)\end{array}$ & $\begin{array}{c}0.0146 \\
(0.0435)\end{array}$ & $\begin{array}{c}-0.000735 \\
(0.0635)\end{array}$ \\
\hline Constant & $\begin{array}{l}0.103 * * \\
(0.0399)\end{array}$ & $\begin{array}{c}0.144 \\
(0.159)\end{array}$ & $\begin{array}{c}0.179 * * * \\
(0.0440)\end{array}$ & $\begin{array}{c}0.232 \\
(0.167)\end{array}$ \\
\hline Observations & 708 & 708 & 708 & 708 \\
\hline R-squared & 0.746 & 0.735 & 0.751 & 0.754 \\
\hline Number of funds & 9 & 9 & 9 & 9 \\
\hline
\end{tabular}

*** $\mathrm{p}<0.01, * * \mathrm{p}<0.05$ and $* \mathrm{p}<0.1$. 